\title{
Honores y renuncias. La escultora argentina Lola Mora y la fuente de los debates
}

\begin{abstract}
Patricia Viviana Corsani ${ }^{1}$
RESUMEN: Lola Mora (1867-1936) fue la más halagada y discutida escultora argentina de los últimos años del siglo XIX y comienzos del siglo XX. La prensa escrita de Buenos Aires sigue el desarrollo de su carrera artística desde la llegada del viaje de estudios en 1900 y la convierte en protagonista principal monopolizando así la atención de los cronistas. El tema de este trabajo de investigación es una de sus obras más conocidas: la Fuente de las Nereidas o denominada popularmente Fuente de Lola Mora, conjunto escultórico de mármol de Carrara que se inaugura el 21 de mayo de 1903 en el Paseo de Julio. Esta investigación abordará las cuestiones que se debatieron en torno a este conjunto escultórico en relación al emplazamiento original en 1903, que lo transforma en un proceso particular ya que hasta ese momento nunca se habían producido discusiones de tales características en torno a una obra decorativa para la ciudad.

PALABRAS-CLAVE: Lola Mora. Fuente. Escultura decorative. Arte público. Desnudos. Buenos Aires.

RESUMO: Lola Mora (1867-1936) foi a mais aclamada e discutida escultora argentina dos últimos anos do século XIX e do início do século XX. A imprensa escrita de Buenos Aires acompanhou o desenvolvimento de sua carreira artística desde a sua chegada de uma viagem de estudos em 1900 e a convertev em protagonista principal, monopolizando assim a atenção dos colunistas. O tema desta pesquisa é uma de suas obras mais famosas, a Fonte das Nereidas, popularmente conhecida como a Fonte de Lola Mora. Trata-se de um conjunto escultural em mármore de Carrara, inaugurado em 21 de maio de 1903, no Paseo de Julio. Nossa investigação abordará as questões debatidas em torno desse conjunto escultural quanto à sua localização original em 1903, que transformaram a discussão em um processo singular, pois, até hoje, nunca houve debates com tais características sobre uma obra decorativa para a cidade.

PALABRAS-CHAVE: Lola Mora. Fonte. Escultura decorativa. Arte pública. Nus. Buenos Aires.
\end{abstract}

1. Instituto de Teoría e Historia delArte Julio E. Payró, Facultad de Filosofía y LetrasUniversidad de Buenos Aires. E-mail: <patricorsan@ hotmail.com $>$. 
2. Dolores Mora nace en la localidad de El Tala, actual territorio de la provincia de Tucumán el 22 de abril, en 1867. Muere en Buenos Aires el 7 de junio de 1936.

3. Respecto a la bibliografía específica sobre la escultora los mayores aportes fueron los de: Oscar Félix Haedo (1974), punto de partida obligado de todos los estudios posteriores que lo citaron incondicionalmente con aciertos y errores. También el libro de los investigadores Carlos Páez de la Torre y Celia Terán (1997) es un trabajo escrito con precisión científica que saca a la luz una parte de la documentación inédita que existe en los archivos de la provincia de Tucumán.

4. Cf. 22.a Sesión Ordinaria... (1895, p. 266).

5. Cf. Decreto... (1899).

6. Falcucci llega a la ciudad de Tucumán en 1887. Nacido en 1856 en Atessa, Chieti, es prácticamente desconocida su obra italiana por nosotros. Incursionó también en la escultura. Muere en Tucumán en 1922 .

7. Había presentado sus pinturas en las Exposiciones de Nápoles (1877) y Turín (1881). Su obra más cuestionada y la mejor según la crítica de arte es Il Voto, que presenta en 1883 en la Exposizione Nazionale di Roma.

8. Era Senador de la ciudad desde 1889 (ENCICLOPEDIA..., 1934, p. 759). Para otros datos sobre sus maestros italianos, véase: $L a$ Nación, Buenos Aires, p. 5, 5 mayo 1899. La Ilustración Artística Argentina (19 oct.1903, p. 686-687).
ABSTRACT: Lola Mora (1867-1936) was the most widely acclaimed and discussed Argentine sculptress of the late $19^{\text {th }}$ and early $20^{\text {th }}$ century. The written press of Buenos Aires began to follow the development of her artistic career as soon as she returned from an academic program abroad in 1900, and placed her at the center stage, thus monopolizing all the columnists' attention. This research revolves around one of her most famous works, namely the Fountain of the Nereids, popularly known as Lola Mora's Fountain. It is a sculptural group carved in Carrara marble and inaugurated on May 21, 1903, on Paseo de Julio. We will be examining the issues that were debated around this sculptural group as to its original location in 1903, which turned the discussion into a unique process, because so far no debate of this nature has ever taken place around an ornamental work for the city.

KEYWORDS: Lola Mora. Fountain. Ornamental Sculpture. Public Art. Nudes. Buenos Aires.

Dedicada por entero a su profesión, la escultura, Lola Mora (18671936) fue la más halagada y discutida escultora argentina de los últimos años del siglo XIX y comienzos del siglo XX². Si bien había algunas artistas que se dedicaban a estas labores en la época, la mayoría son desconocidas debido a la falta de estudios sobre ellas y solo algunos datos, en fuentes hemerográficas, nos dan cuenta de su existencia.

No ocurre lo mismo con la escultora que vamos a estudiar, pues la prensa escrita de Buenos Aires, mientras sigue el desarrollo de su carrera artística desde la llegada del viaje de estudios en 1900, la convierte en protagonista principal, monopolizando así la atención de los cronistas. Esta actitud provocaría que, posteriores historiadores del arte, consideren a Lola Mora la primera escultora argentina y que esté presente en la mayoría de las historias generales sobre arte argentino que se refieren a los inicios de la escultura en el país.

La beca otorgada por el gobierno nacional, que le permitió viajar a Europa y estudiar en los mejores talleres italianos, los encargos de esculturas y los debates que surgieron en torno a algunas éstas, con el transcurso de los años, ayudaron a construir una figura de características peculiares en el arte argentino ${ }^{3}$.

En julio de 1895 Lola Mora había solicitado un subsidio para estudiar pintura en Europa ${ }^{4}$. La Cámara de Diputados de la Nación, en septiembre de 1896, tomando como referencia testimonios y antecedentes de la artista que acreditaban su vocación, le otorga la beca de estudio que duraría dos años. Este subsidio que será renovado en junio de 1899 luego de analizar diversos informes sobre Lola Mora que existían en el Ministerio ${ }^{5}$.

Por recomendación de su maestro tucumano de pintura Santiago Falcuccibi, su destino fué Roma y en particular el taller de Francesco Paolo Michetti (1851-1929), quien había sido escultor en su juventud y que, cuando la escultura lo conoció se dedicaba a la pintura y a la fotografía 7 . En su taller trabajaba el escultor Costantino Barbella (1852-1925), que tenía a su cargo las clases de modelado. Después Lola continuaría estudiando con Giulio Monteverde 11837 1917), un escultor muy prestigioso en Roma y autor de monumentos funerarios y conmemorativos, quien finalmente la convence para que se dedique a la escultura ${ }^{8}$.

Así Lola Mora no hace más que continuar con el tradicional viaje a Italia que, años anteriores, habían concretado otros escultores, considerados los primeros argentinos, como Lucio Correa Morales (1 852-1923) y Francisco 
Cafferata (1861-1890), ambos instalados en Florencia para cumplir su período de aprendizaje en la Real Academia de Bellas Artes con Urbano Luchessi el primero y con los maestros Luchessi y Augusto Pessaglia el segundo?.

El eje de este trabajo de investigación es una de sus obras más conocidas por cierto, la Fuente de las Nereidas o denominada popularmente Fuente de Lola Mora, conjunto escultórico de mármol que se inaugura el 21 de mayo de 1903 en el Paseo de Julio (actual calle Leandro N. Alem, entre Bartolomé Mitre y ex Cangallo, hoy Juan Domingo Perón en la ciudad de Buenos Aires) ${ }^{10}$ (Figura 1). Posteriormente, en diciembre de 1918, el grupo escultórico fue trasladado al sur de la ciudad (Costanera Sur) donde permanece.

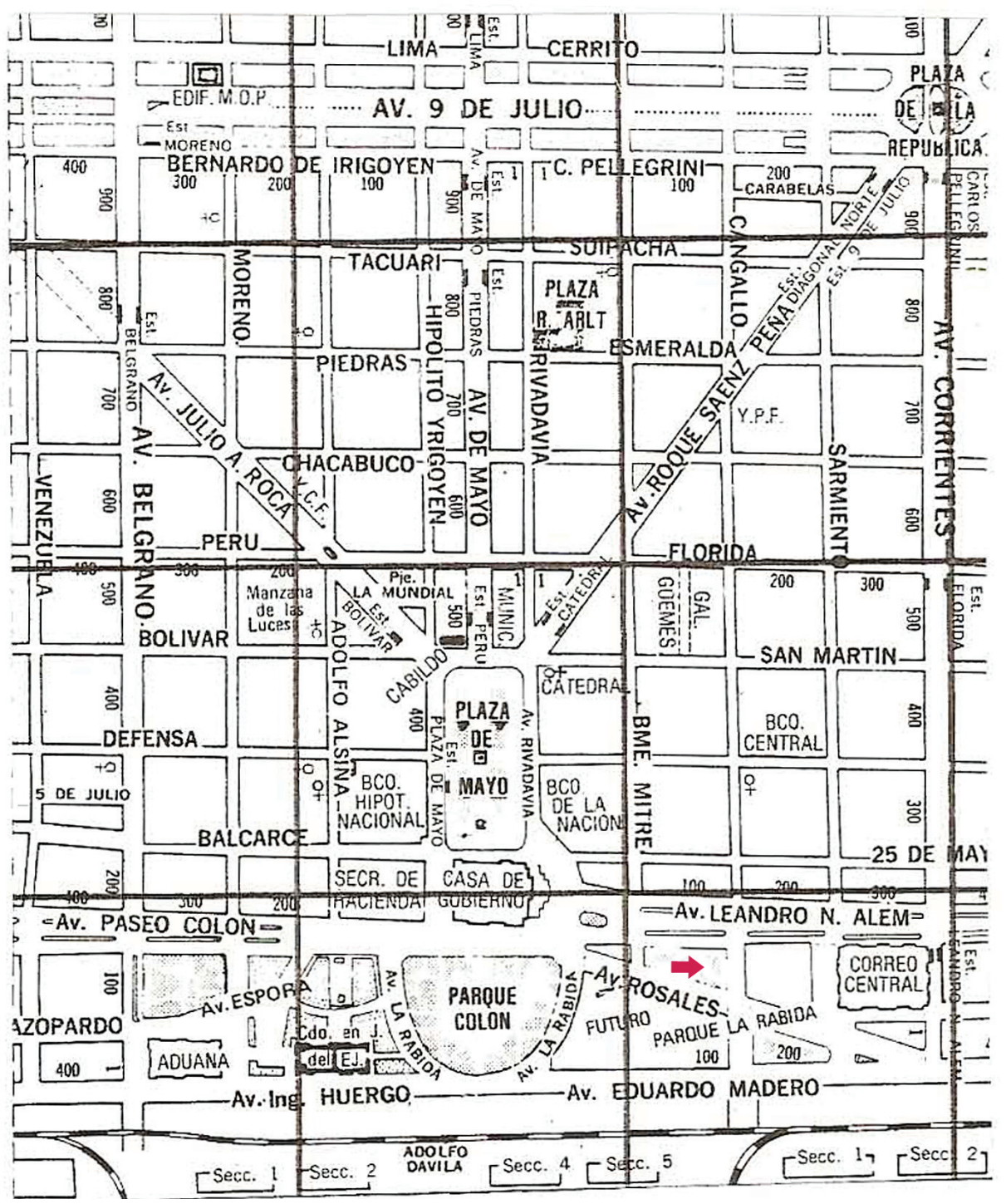

Figura 1 - Plano de la zona de la ciudad de Buenos Aires donde fue emplazada la fuente (c. 1980). Detalle
9. Cf.Adrián Merlino (1954, p. 67, 96-97). Lucio Correa Morales regresó al país en 1882 y Cafferata estuvo en Europa entre 1877 y 1885 .

10. La obra fué trasladada de su sitio original, y, desde el 8 de diciembre de 1918 está emplazada en la Costanera Sur.Véase: Patricia V. Corsani (2002).

La Ordenanza 49.292 del 15 jun. 1995 del Concejo Deliberante (C. E. 43.841/95) de la Ciudad de BuenosAires declaró "Sitio de Interés Cultural" a la fuente de las Nereidas emplazada en la in tersección de la Avenida Tristán Achával Rodríguez, Pedro Luis Migone,Avenida Costanera Sur y Brasil. Datos en: Carpeta correspondiente a la obra ( ${ }^{\circ} 22$, circunscripción $13 \mathrm{~A}$ ), Archivo de la Dirección de Paseos y División de Monumentos y Obras de Arte (MOA) de la Municipalidad de la Ciudad de Buenos Aires. 
11. La Comisión Municipal, con 22 miembros elegidos con acuerdo del Senado, comienza su mandato el 21 dic.1901 (HONORABLE... , 1901). Una buena parte de dicha comisión participará de los debates que nos ocupan en esta investigación. Véase Ismael Bucich Escobar (1930, p. 264-265)

12. Véase Adrian Gorelik (1998, p. 138-139).

13. Cf. Clara Braun y Julio Cacciatore (1996)

14. Idem. p. 36-38.

15. Adolfo Bullrich (18331904) fue Intendente Municipal durante la segunda presidencia de Julio A. Roca entre octubre de 1898 y octubre de 1902. Debido a problemas de salud, viaja a París previa renuncia a su cargo y allí muere. Lo sucede en el cargo Alberto Casares (GIANELLO; PICCIRILLI; ROMAY, 1954,p. 723). Los períodos presidenciales de Julio A. Roca fueron:primera presidencia: 1880-1886; segunda presidencia: 1898-1904.
Ahora bien, el conjunto escultórico que nos ocupa es tema de estudios e interpretaciones de artistas e investigadores. Mostrada en el cine e imagen incorporada a la publicidad de todas las épocas, es la primera obra que la escultora trae al país para ser emplazada en un espacio público. Autora y fuente son inseparables en el imaginario colectivo.

La fuente de mármol de Carrara ha sido admirada, criticada y en torno suyo se originaron debates en los momentos previos y posteriores a su primera ubicación.

Para algunos concejales de la Comisión Municipal, la fuente era sinónimo de lujo, gastos y conflictos. Otros en cambio, defendían el emplazamiento de esculturas decorativas para los paseos públicos de una Buenos Aires que aspiraba a ser una ciudad moderna.

Para el pueblo, la fuente fue una obra maravillosa que embellecía la ciudad y a la que aceptó con entusiasmo.

Esta investigación abordará las cuestiones que se debatieron en torno a este conjunto escultórico en relación al emplazamiento original en 1903. Largas gestiones parecieron hacer interminable la discusión sobre la adquisición y el pago de la fuente, que a la vez demoraron su instalación. Debates que duraron meses y se desarrollaron en varias sesiones de la Comisión Municipal, que evidencia la confrontación entre el jefe municipal y dicha Comisión y que parecen convertir a la fuente en un "problema de estado"11. Su costo se convierte en una excusa para sacar a la luz un fuerte conflicto político que excede lo meramente artístico. Este debate de ribetes inusitados lo transforma en un proceso particular ya que hasta ese momento nunca se habían producido discusiones de tales características en torno a una obra decorativa para la ciudad.

Hermosear Buenos Aires

Torcuato de Alvear fue el primer Intendente de la ciudad de Buenos Aires. Entre 1880 y 1882 estuvo al frente de la Comisión Municipal para luego seguir a cargo de la Intendencia entre 1882 y $1887^{12}$. En una ciudad que recibiría, entre 1857 y 1914, a 3.300 .000 inmigrantes $^{13}$, lo que provocará una fuerte europeización en la cultura, Alvear impulsa cambios radicales durante su gestión: se derriban edificios como la Recova, se mutilan tres arcos del Cabildo para abrir la Avenida de Mayo. Como capital política y económica tiene a Europa como modelo y la ciudad de París será tenida en cuenta al diseñar un nuevo trazado urbano ${ }^{14}$. También se proyectan espacios públicos como lugares de esparcimiento al aire libre, y, a los que se agrega la presencia de esculturas y elementos decorativos según modelos de jardines públicos franceses.

Desde octubre de 1898 Adolfo J. Bullrich se hace cargo de la intendencia de la ciudad. Un hombre de negocios que ocupó esa cartera por dos períodos consecutivos, nombrado por el Presidente de la República Julio Argentino Roca ${ }^{15}$. Durante su mandato se implementaron distintas obras públicas 
como el trazado de nuevos jardines y paseos, la pavimentación de calles y construcción de edificios, el desarrollo de la red de tranvías eléctricos y el alumbrado eléctrico.

Para los hombres de esta generación, llamada "del 80", de corte liberal y positivista, el interés era transformar al país en una nación civilizada. Su proyecto civilizatorio los llevaría a transitar hacia el progreso material y, en ese camino, el arte ocupaba un lugar fundamental.

$Y$, en el marco de los proyectos de embellecimiento y modernización de Buenos Aires desde finales del siglo XIX, la ubicación de esculturas decorativas y monumentos conmemorativos en espacios públicos ocupó un lugar importante pues se aspiraba a seguir los modelos de plazas y paseos parisinos. Rememorar, educar el gusto del paseante, embellecer la ciudad para hacerla agradable a la vista eran las consignas a seguir por esos años.

Como escribe Maurice Agulhon, las fuentes ornamentales fueron la moda en el siglo XIX. La fuente de planta circular, era la apropiada para ubicar en el centro de una plaza y se organizaba en torno a un eje de simetría vertical ${ }^{16}$. Mezcla de utilidad y ornamentación, las fuentes conformaban el decorado urbano en ese afán por realizar obras públicas en la ciudad con miras al progreso. En Buenos Aires, la Intendencia Municipal había comprado dos fuentes decorativas, ambas de hierro, fundidas en la casa francesa Du Val d'Osne, que estaban emplazadas en la Plaza de la Victoria en torno a $1870^{17}$ (Figura 2). Torcuato de Alvear quería comprar una fuente en Europa para la Plaza 11 de Septiembre pero finalmente no lo hizo ${ }^{18}$.

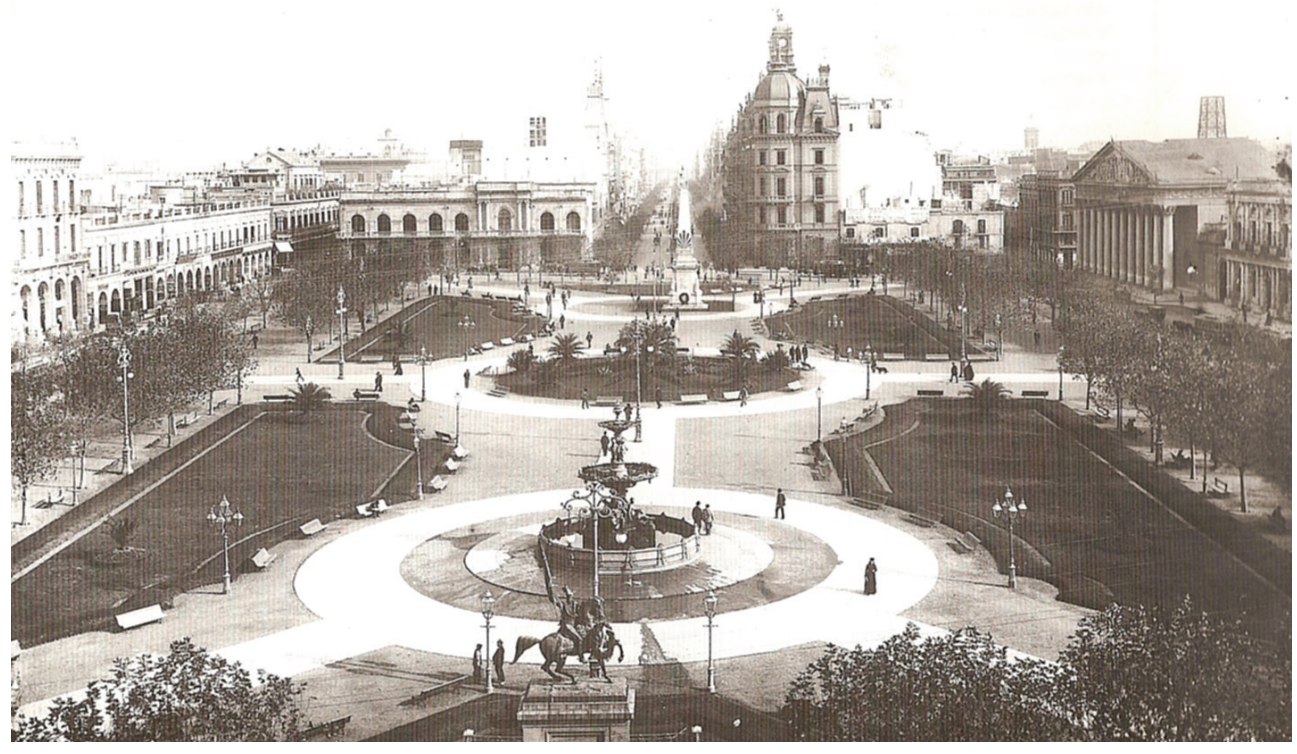

Figura 2 - Plaza y Avenida de Mayo a fines del siglo XIX. Archivo Fotográfico del Archivo General de la Nación (BERJMAN, 1998, p. 157).
16. Cf. Maurice Agulhon (1994, p. 107-108).

17. Cf. Oscar Félix Haedo (1978, p. 15-16).

18. Cf. Sonia Berjman (1998, p. 73). 
19. Cf. Rodrigo Gutiérrez Viñuales (2004, p. 166).

20. Para estudiar más profundamente estos proyectos, véase: Raúl Piccioni (2000); Patricia V. Corsani (2000).

21. Cf. Marina Aguerre y Raul Piccioni (1998).

22. Citado en:Sesión Ordinaria del 5 sept.1902. In: Actas de la Comisión Municipal de la Ciudad de Buenos Aires. Correspondientes al año de 1902. Buenos Aires, Tip. Del Asilo de Reforma de Menores Varones, 1903, p. 438.

23. El Diario, Buenos Aires, p. 1, 22 agosto 1900 .

24. Sesión Ordinaria del 5 sept. 1902 (1903b).
Las fuentes públicas eran lugares de encuentro, tenían una utilidad social en relación a la higiene y la gente se sentía seducida mirando el dinamismo que provocaban los chorros de agua ${ }^{19}$.

En fin, la propuesta de ornamentar los paseos ya comenzando el siglo $X X$, se complementa y se organiza con el impulso que dan los pintores Eduardo Schiaffino (1858-1935) y Ernesto de la Cárcova (1 867-1927). El primero lo hace a través de sus artículos publicados en el periódico La Nación, y, el segundo, desde su gestión como Concejal en la mencionada Comisión Municipal, en la que trabajó entre 1901 y 1907. Intenciones y tareas que culminarán en un proyecto presentado y aprobado a través de una Ordenanza del 17 de noviembre de 1903, punto de partida de un plan orgánico de adquisiciones de esculturas decorativas en Europa ${ }^{20}$. Considerando al arte ornamental como una forma de arte público, se planeó la compra de esculturas desde algún país con prestigio artístico (Francia, Italia, Bélgica) ${ }^{21}$.

En ese contexto previo de proyectos, inquietudes, planes y deseos de trabajar por una estética urbana, se inserta la historia que nos ocupa, la cual comienza con el regreso de Lola Mora procedente de Europa después de su viaje de estudios el 4 de agosto de 1900. Días después - el 21 de agostose firmó el contrato de adquisición de la fuente entre la intendencia y la escultora. Las bases del contrato habrían sido propuestas por la misma Lola Mora:

1․ Que el costo de esa fuente sería de 25.000 pesos moneda nacional, ejecutándose en mármol de 1‥ Calidad y tendría una altura de ocho metros poco más ó menos.

$2^{\circ}$. Que esa obra podría realizarse dentro de un plazo de diez meses y conforme á la fotografía que se adjuntaba á la propuesta.

3․ Que el pago de dicha obra se efectuaría en tres cuotas: la 1ํ․ De 5.000 \$ al empezarla, la segunda de 10.000 \$ una vez que hubiese sido pasado al yeso y la tercera también de 10.000 pesos á su completa terminación y que fuera entregada embalada al Sr. Ministro Argentino en Italia, por intermedio del cual debería hacerse también, el pago de cada una de las cuotas, debido á que la señorita Mora, pensaba ejecutar esa obra en la ciudad de Roma ${ }^{22}$

El trabajo se llevaría a cabo en Roma para abaratar costos y evitar el traslado de los bloques de mármol. Así se tendría la seguridad de la calidad y pureza del material que debía "ser de un blanco perfecto, y que sería imposible devolver en caso de salir defectuoso" 23.

El 10 de septiembre del 1900 el Departamento Ejecutivo aceptó la propuesta de la escultora "considerando, que los Parques y Paseos del Municipio, carecían de esta clase de trabajos artísticos que tanto contribuyen á la cultura de un país, como también fundándose en que corresponde á las autoridades fomentar el desarrollo del arte nacional"24.

En Buenos Aires no eran tantos los escultores que se dedicaban al oficio a comienzos de siglo XX: Francisco Cafferata había fallecido años antes, trabajaban Lucio Correa Morales y Mateo Alonso, además de algunos extranjeros como el italiano Victor De Pol (1865-1925). De una generación más joven son 
Rogelio Yrurtia (1879-1950) y Pedro Zonza Briano (1 886-1941), que todavía estaban en su etapa de formación.

Lola Mora no fué la única mujer argentina escultora que trabajaba por esos años. Por ejemplo se conoce el nombre de Herminia Pallay, aunque no hay mayores datos sobre esta escultora en la prensa o en diccionarios de artistas, por lo que se convierte hasta el momento en una desconocida para nosotros ${ }^{25}$. También Josefa Aguirre de Vasilicós, una pionera en la escultura, quien se casa con el cónsul general de Grecia en Argentina y viaja por Europa donde estudia escultura $^{26}$. Si bien Vasilicós es la antecesora de Lola Mora, no podemos asegurar que no haya habido otras contemporáneas interesadas de las que no se conservan registros.

Volvamos al estudio de la fuente y a la escultora, quien habría llevado a cabo dos maquetas de la fuente, ambas de paradero desconocido. Una de éstas, modelada en arcilla es descripta por El Diario del 7 de agosto de 1900:

Consta esta primorosa y original concepción, esbeltísima y de una gracia llena de nobleza, de tres cuerpos: constituyen el primero, ó sea el gran pilón inferior, tres grandes conchas de mármol reunidas, sobre cuyo centro se asienta un bloque rústico de granito azulado, de abajo del cual salen á escape en tres direcciones tres potros que, como libertándose con fiero esfuerzo, surgen encabritados chapoteando el agua de cada uno de los tres pilones formados por las valvas recipientes.

Es hermoso el arranque bravio [sic] de los potros, cuya fuga detienen en plena carrera, encorbándoles el cuello, atletas que á su paso surjen [sic] del agua sacando á medias el cuerpo vigoroso y muscular. [...] [en el nivel medio] se apoyan las sirenas sobre sus caudas hermosas, retorcidas con arte en torno del coronamiento del bloque, y yerquen el bello cuerpo femenino sustentando en sus brazos con esfuerzo una gran concha igual á las tres de abajo, en cuyo borde caprichoso está sentada Vénus [...] sentada sobre una pierna, deja la otra pendiente en el aire con una verdad anatómica soberbia, -su cuerpo delicado medio se tuerce para poder asomarse la diosa al espejo del agua; es toda su postura de una naturalidad absoluta en el genial atrevimiento de aquella ubicacion tan novedosa y arriesgada ${ }^{27}$.

La iconografía del nacimiento de Venus, de larga tradición en la historia del arte había sido el tema elegido por la escultora ${ }^{28}$. Describe la figura de la diosa de las aguas, que surge de una gran concha marina sostenida por dos nereidas con cuerpo femenino hasta los muslos y doble cola de pez escamada en la parte inferior de sus anatomías. En la parte inferior de la fuente grupos de caballos encabritados están sostenidos con vigor por figuras masculinas desnudas ${ }^{29}$.

A esta descripción se suma la fotografía publicada del proyecto por la revista Caras y Caretas del 18 de agosto de 190030, haciendo referencia a su destino: "para la Plaza de Mayo". Esta foto es el único documento conocido sobre el boceto en cuestión, pues en ella se observa claramente el planteo general que encontramos en la obra terminada (Figura 3). Este es el proyecto que acepta la intendencia en esa ocasión y había sido la maqueta ganadora del Premio en "La Promotrice", concurso anual que se llevaba a cabo en Roma, entre artistas
25. Fueron consultados los siguientes diccionarios: Vicente Gesualdo (1969); Adrián Merlino (1954); Lily Sosa de Newton (1986).

26. Cf. Adriana Van Deurs y Marcelo Renard (1996); Josefa Aguirre de Vasilicós (18381913), datos extraídos de Lily Sosa de Newton (1986, p. 17).

27 El Diario, Buenos Aires, p. 1, 7 agosto 1900 .

28. Cf. Oscar Félix Haedo (1974, p. 25-26).

29. Se conoce que algunos de sus modelos masculinos fueron el esgrimista Agesislao Greco, el marqués de San Giovanni y el hijo de Daniel Muñoz, representante del Uruguay en Italia.Cf. Caras $y$ Caretas (1903a).

30. Cf. UNA ARTISTA argentina. Caras y Caretas (1900). 
31. Esto se relaciona con la nota aparecida en La Prensa, Buenos Aires, p. 8, 20 jun. 1901, donde se habla del traslado de la pirámide de Mayo al centro de la plaza.

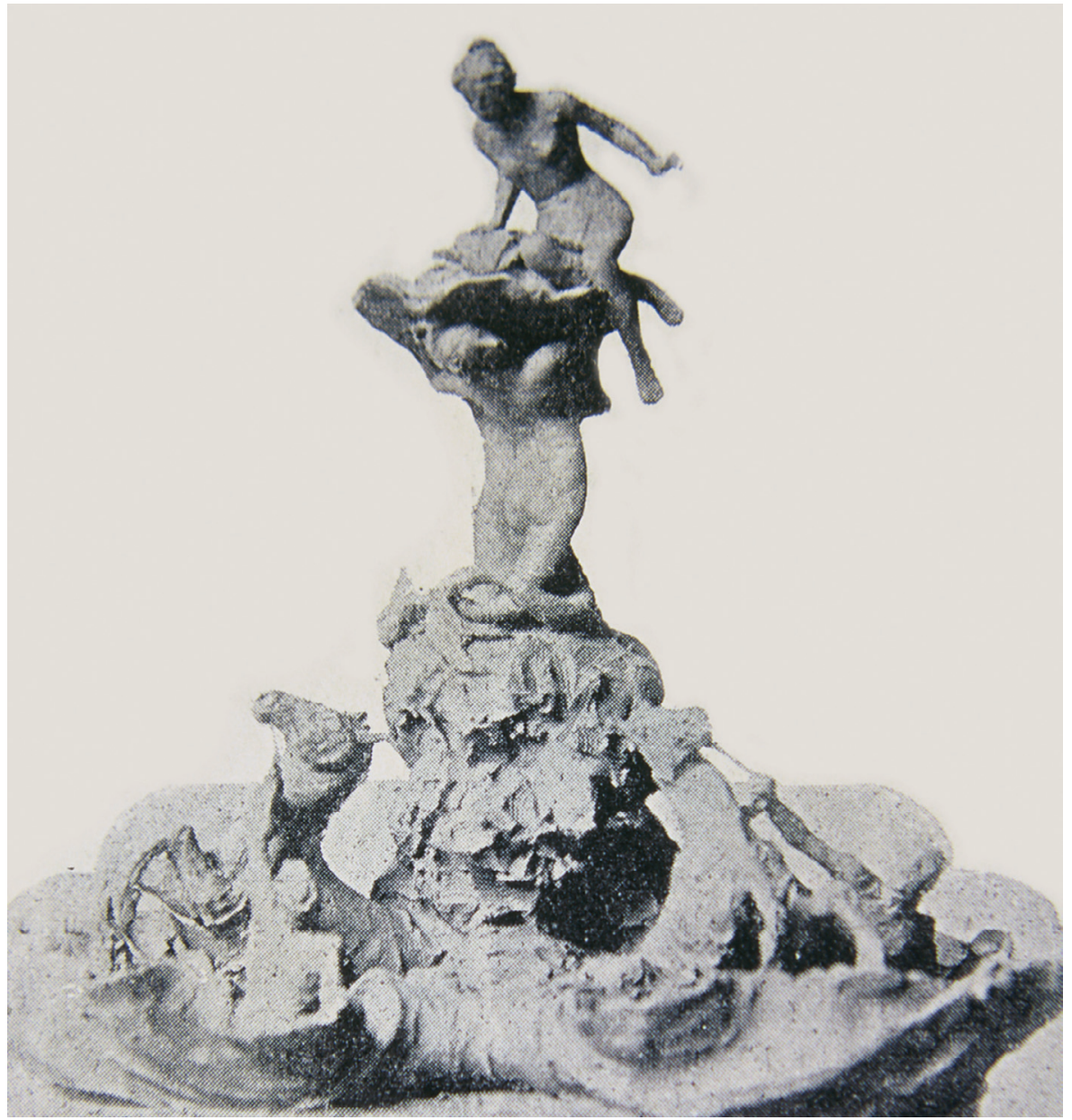

Figura 3 - Maqueta de la fuente. Foto publicada en Una artista argentina. Caras y Caretas, Buenos Aires, año 3, n. 98, 18 agosto 1900 [s. p.].

jóvenes. Lola Mora la realizó para concursar en dicho certamen en el que compitió con otras 40 esculturas.

La segunda maqueta, modelada en yeso, se conoce por un artículo publicado en La Nación, el 23 de abril de 1901, que incluye una fotografía de muy mala calidad que hace difícil la observación de detalles. El periodista acreditado en Roma escribe que la fuente está "destinada a sustituir a la pirámide de mayo en la plaza homónima cuando aquélla sea trasladada" ${ }^{\prime 31}$. La descripción es la siguiente:

El argumento de la obra es mitológico [...]. Representa al dios Nereo, á quien circundan sus hijas, tan bellas y atrayentes como para poder con el simple encanto de su hermosura, la fascinación de la mirada y la seducción que fluía de sus cuerpos divinamente modelados, amansar á los grandes monstruos marinos que, según la fantasía griega, poblaban el océano. 
[...] Un amorcito que cuchichea al oído de una nereida, insinuando quizás consejos maliciosos, constituye un detalle general del boceto, que promete muchísimo ${ }^{32}$.

El cronista asegura que la foto que envía es la que corresponde a la fuente que Lola Mora lleva a cabo para la Plaza de Mayo, lo cual es curioso ya que el primer boceto había sido presentado y aceptado en agosto del año anterior. Seguramente era éste uno de los últimos proyectos de la escultora para su fuente que quizás habría dejado de lado por ella misma en Italia. En cuanto al posible emplazamiento en la Plaza de Mayo, este sitio aparentemente elegido en las instancias iniciales, se deja de lado posteriormente, sin que tengamos precisiones sobre las causas de estos cambios. Ya cuando la escultora regresa en septiembre de 1902, el sitio de emplazamiento es desconocido. Sin embargo, resulta significativo, que con el proyecto inicial presentado, ya se tenía certezas de las figuras que formarían parte del conjunto: los seres mitológicos desnudos, y, posiblemente se consideró que no eran aptas para ser ubicadas frente a la Iglesia Catedral.

Debates en la Comisión Municipal antes de la llegada de la fuente

En marzo de 1902, mientras La Nación da cuenta que la escultora viajaría en el mes de junio a Buenos Aires trayendo parte de la fuente artística, surge un debate en el seno mismo de la Comisión Municipal ${ }^{33}$.

Mientras el destino de la obra se hacía desconocido e incierto, el debate se agudizaba cuando el Intendente Bullrich autoriza el pago de \$25.000 a la escultora sin solicitar autorización a los miembros de la Comisión Municipal. Es interesante bucear en la documentación existente en la Biblioteca del actual Concejo Deliberante, que guarda los registros, actas y diarios de las sesiones. Es notable el hecho de la sucesión de extensos debates que tienen lugar entre abril y diciembre de 1902, momento álgido que se retoma con vigor al año siguiente (entre mayo y junio de 1903, después de la inauguración).

Así, el pago aprobado por el Intendente produce entonces una reacción que se materializará en una resolución de fecha 18 de abril de 1902 de la Comisión Municipal:

Pago ilegítimo a la señorita Lola Mora.

Artículo 1․ Declárase ilegítimo el pago de $(25.000 \$ \mathrm{~m} / \mathrm{n})$ veinte y cinco [sic] mil pesos moneda nacional, verificado por la Intendencia, sin la competente autorización del Concejo Deliberante, á la señorita Lola Mora, como precio de la fuente contratada para el Parque 3 de Febrero. [... $]^{34}$.

La Comisión Municipal lo acusaba de abusar de sus facultades al comprar la fuente sin su autorización, pues la Ley Orgánica limitaba esas facultades en relación a contratos cuyo valor sea superior a $\$ 500^{35}$. Acusaciones al
32. La Nación, Buenos Aires, p. 3, 23 abr. 1901 .

33.La Nación, Buenos Aires, p. 3, 22 marzo 1902 .

34. Resolución del 18 abr. 1902 (1908, p. 59).

35. Sesión Ordinaria del 6 jun. 1902 (1903, p. 295-296). El artículo 59 inciso 14 de la Ley Orgánica de la Municipalidad de la Ciudad del 23 oct.1882, determina: "Celebrar contratos ó autorizar trabajos dentro del presupuesto, cuando el valor de los contratos ó trabajos no exceda de quinientos pesos, debiendo hacerse por licitación aquellos que excedan de 1000 pesos". Véase la publicación del Concejo Deliberante de la Ciudad de Buenos Aires (1963, p. 88). 
36. La Voz de la Iglesia, Buenos Aires, p. 2, 23 mayo 1902.

37. La Voz de la Iglesia, Buenos Aires, p. 2, 12 jun. 1902.

38. El Diario, Buenos Aires, p. 2,18 jun. 1902 .

39. Cf. Carlos Páez de la Torre y Celia Terán (1997, p. 38).

40.Véase Sesión de Prórroga del día 8 jul. 1902 (1903, p. 354-355). Esta decisión será analizada en la sesión del 5 de septiembre ya con la escultora y su obra en la ciudad. magistrado y discusiones en torno a ésta que evidencian ciertas "irregularidades" a la hora de encargar la fuente y que hacen que éste se justifique remitiéndose a leyes que lo avalarían. Agrega que la obra "se ha abonado con fondos del gobierno de la nación y se ha adquirido con autorización competente." ${ }^{36}$ La "autorización competente" en este caso y como se mencionará más adelante, había sido la del mismo Presidente de la Nación Julio A. Roca.

A partir de esta discusión, y enterada Lola Mora de estos conflictos decide vender su obra a Estados Unidos aprovechando distintos ofrecimientos, entre los que se encontraba el del intendente de la ciudad de San Francisco en California por un monto de 150 mil francos. Envía una carta a Bullrich (fechada el 25 de mayo) en la que le pide autorización para rescindir el contrato firmado con la municipalidad respecto de la fuente y estaría dispuesta a devolver el dinero que se le adelantó.

Frente a esta situación, el intendente Adolfo Bullrich acepta la venta por \$ 25 .000.- a la municipalidad de Minnessota (Estados Unidos), decisión que toma ante la postura intransigente de la Comisión que no solo no reconocía su facultad para comprarla, sino que también le exigía que pagase el costo de la obra con dinero propio ${ }^{37}$.

Solicita a la Comisión autorización para venderla al país extranjero, caso contrario se efectivice el pago de cinco mil pesos a la artista que quedaron pendientes. Es necesario recordar que aun en esta instancia la obra estaba aún en Europa casi terminada, pues Lola Mora había dejado pendiente para trabajar en Buenos Aires solo una de las figuras, si es que finalmente la comisión rechazara la propuesta de la venta.

Un dato a tener en cuenta en esta instancia, es la intervención en este asunto del Ministro Enrique Moreno, Embajador argentino en Italia, y del mismo Presidente de la República Julio A. Roca para que la obra no fuese vendida al exterior y fuese emplazada en la ciudad de Buenos Aires:

El ministro argentino en Roma doctor Moreno, admirador y protector de la artista, ha pedido á esta que por patriotismo, desista de su propósito de vender la fuente y la mande á Buenos Aires, como está convenido.

El presidente de la República, por cuya órden [sic] se mandó construir la fuente, ha resuelto que esta sea traida y colocada en el paraje que se le ha destinado ${ }^{38}$.

Moreno había sido un fiel protector de la escultora en Roma ${ }^{39}$ y ella misma era amiga de Julio A. Roca y de su familia. Dos miembros de la clase política que avalaron incondicionalmente el trabajo de Lola Mora en estos años, uno de ellos desde Europa $y$, el segundo en Buenos Aires, interviniendo directamente para que se concretara el envío a la ciudad.

Mientras tanto, en la Comisión Municipal, la fuente seguía dando que hablar, se analizaron los antecedentes de la compra y quedó en manos de la Comisión de Obras Públicas decidir si aprobaba o rechazaba la adquisición, que conformaban el pintor Ernesto De la Cárcova, Alberto Rodríguez Larreta y Eduardo de Estrada ${ }^{40}$. 
Las esculturas en Buenos Aires

Al llegar a Buenos Aires, en septiembre de 1902, Lola Mora se presenta ante el intendente municipal para solicitar directivas respecto al sitio en el que se emplazaría la fuente. Sin embargo, el funcionario todavía esperaba la resolución de la Comisión Municipal y así fue que

Nada se convino en definitiva sobre el sitio y ubicación que habrá de darse á la fuente, aunque parece que prima la idea de que sea levantada en los terrenos donde se encontraba antiguamente la estación central de ferrocarriles ${ }^{41}$.

Para que pudiese terminar la obra se hacía necesario levantar un galpón cerca del futuro emplazamiento. Este galpón se instaló frente a la fachada posterior de la Casa de Gobierno, en la Plaza Colón ${ }^{42}$ (Figura 4).

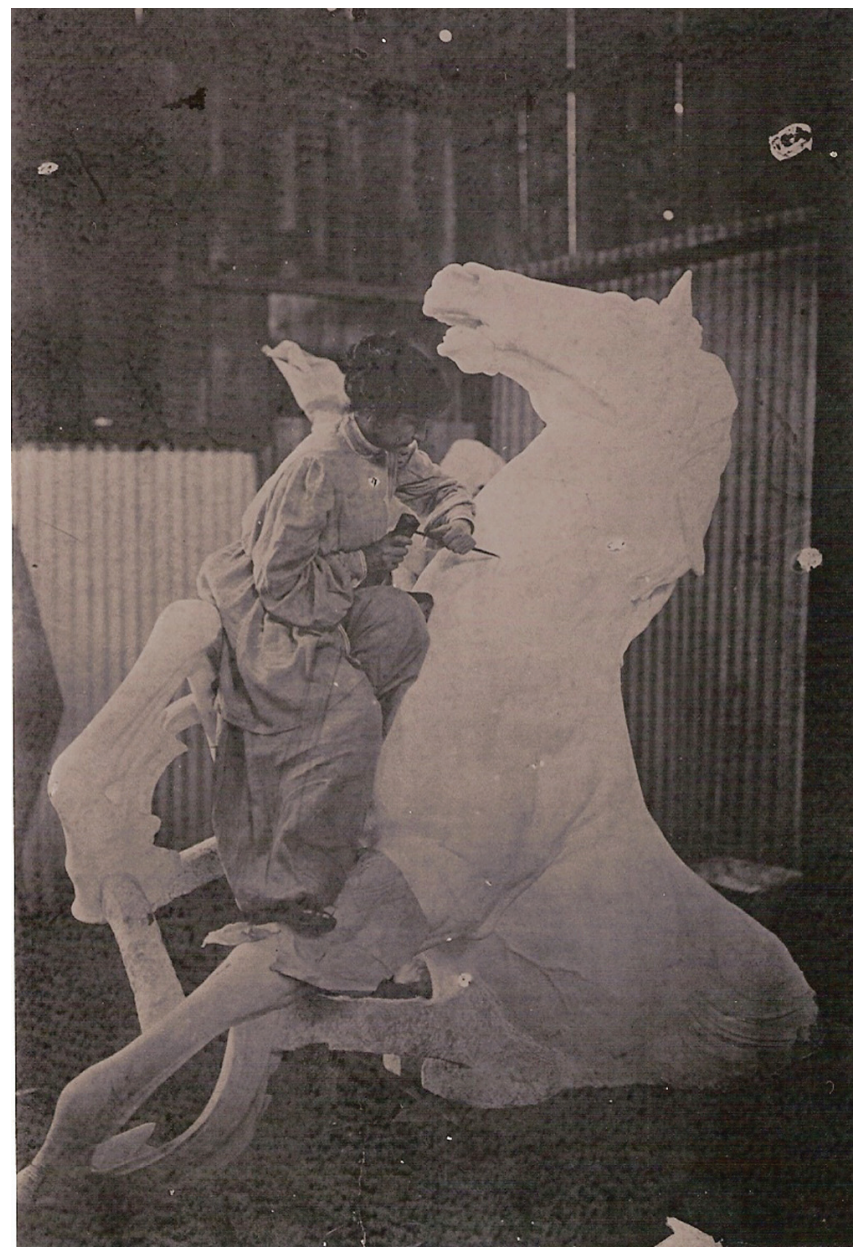

Figura 4 - Lola Mora en el taller provisorio de Paseo de Julio (enero de 1903). Caja 1210, foto 111.319 , Archivo Fotográfico del Archivo General de la Nación, Buenos Aires.
41.La Nación, Buenos Aires, p. 3, 2 sept.1902. Para conocer detalles sobre la llegada de las esculturas desde Italia, véase Corsani (1999).

42. Las fotos de los trabajos fueron publicadas en Arte y Artistas de Caras y Caretas (1903a) 
43. Véase, de la Honorable Comisión Municipal, la versión taquigráfica de la sesión celebrada el día 5 de septiembre de1902, p. 32

44. La Nación, Buenos Aires, p. 3, 13 sept. 1902.

45. El Diario, Buenos Aires, p. 1, 23 sept. 1902.

"Con unos ú otros pretextos se le ha hecho sacar hace dias [sic] del galpón útiles y herramientas y en vano pide que se le devuelvan aquellos, sin los que no es posible trabajar." Este extraño episodio, ocurrido pocos días antes de la fecha prevista para la inauguración de la fuente, fue relatado por El Diario, Buenos Aires, p. 4, 9 mayo 1903.

46. El Diario, Buenos Aires, p. 1, 23 sept. 1902 .

47. Véase, de la Honorable Comisión Municipal, la versión taquigráfica de la sesión celebrada el día 5 de septiembre de1902, p. 30.

48. El Diario, Buenos Aires, p. 2, 22 marzo 1902 .

49. Cf.Caras y Caretas (1900).
Varios fueron los inconvenientes que la escultora debió afrontar durante ese período de labor. Primero un accidente durante la descarga de 26 cajones $^{43}$ produce la rotura de uno de los trozos de mármo ${ }^{44}$. A esto le siguieron constantes reclamos a la municipalidad para que mande a techar el galpón que iba a albergar los mármoles que aún no habían sido desembalados, para que no quedaran a la intemperie, y el pedido de devolución de sus herramientas de trabajo que días antes se habían llevado ${ }^{45}$. Demoras y atrasos que los diarios capitalinos van relatando a través de sus páginas destacando la lentitud de la intendencia en el asunto: "Al paso que van los trabajos para la construcción de la fuente [...], ésta no la veremos terminada en todo el año." ${ }^{46}$.

La sesión del 5 de septiembre de 1902 es muy enriquecedora dado los diversos aspectos que se trataron del problema. Por un lado se plantea el desconocimiento de cómo era realmente el conjunto escultórico. A eso sigue la manifestación de algunos concejales que tenían especial interés en separar los "errores" del Intendente del rol de la artista, y, un tercer tópico está referido a los gastos para emplazar la obra.

Un despacho de la comisión de Obras Públicas firmado por Eduardo Aguirre y Ernesto de la Cárcova, días después de la llegada de la escultora, plantea, curiosamente, que no han tenido la posibilidad de analizar la obra en detalle:

Ahora bien y respecto a las condiciones artísticas de esa fuente, esta comisión se ha encontrado con dificultades para apreciarla pues como único elemento de juicio, le ha sido presentado un croquis muy sucinto, aparecido en un diario de esta capital con fines informativos, y el que si bien bastaría para dar una idea de su conjunto y revelar que se trata de una fuente de carácter ornamental, apropiada para un paseo público, no es, sin embargo, ese grabado periodístico, elemento suficientemente eficaz, para juzgar del verdadero valor artístico que se le atribuye y para lo cual hubiera sido necesario el boceto mismo o fotografías de los diversos aspectos de esa obra.

En cuanto al costo de la referida fuente, la misma carencia de esos elementos de juicio á que hace referencia anteriormente la comisión, la inhabilitan para poder hacer una apreciación más ó menos exacta al respecto; pero, tratándose de una obra de carácter artístico, que debiera ser construída en mármol estatuario de primera calidad y de grandes proporciones, piensa esta comisión que puede considerarse equitativo dicho precio ${ }^{47}$.

Este pasaje de la sesión plantea por vez primera una cuestión que tiene relación con la estética de la obra pero que apenas queda en un planteo esbozado. Pero llama la atención el hecho que, habiendo sido publicadas las fotografías, en fuentes hemerográficas citadas anteriormente, los integrantes de la Comisión de Obras Públicas, no las hubiesen visto. Posiblemente la comisión se refiere al dibujo publicado por El Diario en el mes de marzo de ese año, es decir, seis meses antes del testimonio de Aguirre y De la Cárcova ${ }^{48}$. O, a la maqueta que Caras y Caretas presentaba en agosto de 190049. Todo esto se plantea en esta etapa en que la obra llega a la ciudad, un problema que sale a la luz ante las demoras por las instancias administrativas.

Se agrega a esto la información sobre el destino de la fuente que hasta estos días había sido contradictoria. Para entonces se hablaba de Plaza 
de Mayo, Parque Colón, también de lugares alejados del centro como Parque Patricios, Mataderos y el Parque 3 de Febrero al tiempo que se afianzaba la idea de los terrenos de la ex estación de ferrocarril.

Si bien se deja en claro que la Comisión de ninguna manera aceptaba la forma en que se había contratado el trabajo de Lola Mora, decisión unívoca del Intendente, se separa el problema político-administrativo de la situación de la artista, única víctima de esos debates y demoras. Algunos concejales reaccionan defendiendo los derechos de la escultora a cobrar ese dinero, dejándola al margen de las responsabilidades que le competían únicamente al Intendente.

El tercer tópico en el que se trabaja en la misma sesión es el tema de los gastos que demandaría la colocación de la fuente.

Mientras Lola Mora esperaba con las obras casi concluídas a que decidieran construir la base de la fuente y se procediese a su colocación para evitar que las obras corrieran riesgos ${ }^{50}$. Los diarios se hacían eco de todos los inconvenientes y de la indiferencia del Intendente hacia los trabajos de los cimientos, demorados por dos meses y lo exhortan a que realice lo necesario para agilizar el emplazamiento de la obra. A esto se suma el retraso de la instalación a pesar de estar concluída la obra:

Hace ya muchos días que esta artista tiene terminados sus trabajos para colocar la fuente de que es autora en el paraje designado por la municipalidad, y sin embargo, aun no se han empezado á construir los cimientos que han de sostener la obra, que constituye un orgullo para el arte nacional ${ }^{51}$.

En fin, recién el 23 de diciembre se hace pública una licitación para construir el basamento de piedra de la fuente:

INTENDENCIA MUNICIPAL DE LA CAPITAL- - Licitación para la construcción de un basamento de piedra para la fuente que construye la Srta. Lola Mora. De acuerdo con el pliego de condiciones que puede consultarse en esta secretaría (sección Obras Públicas), llámase á licitación para el 29 del corriente, á las 3.30 p. m. - Buenos Aires, diciembre 23 de 1902. - El secretario ${ }^{52}$.

Mientras se esperaba el basamento, dos de las esculturas fueron expuestas al público en la Exposición Permanente de Industrias Nacionales (en el antiguo Teatro Nacional) que se inauguró el 15 de diciembre y que contó además con pinturas de Schiaffino, Della Valle, Rodríguez Etchart, Sívori, y, esculturas de Alonso y Correa Morales, entre otros. Anuncia La Nación: "[...] La Srta. Lola Mora expondrá, la noche en que se inaugure la exposición, el 'Atleta' y la 'Venus' de la fuente adquirida por la municipalidad y que se está colocando en la plaza Colón" 53 .

Si bien hay pocos datos sobre esta exposición porque fue poco difundida, es paradigmática en la carrera artística de Lola Mora por ser una de las pocas, si no la única, que se conoce donde ella expuso con otros artistas contemporáneos.
50. La Nación, Buenos Aires, p. 6, 17 nov. 1902 ; idem, p. 3, 21 nov. 1902.

51.La Nación, Buenos Aires, p. 3,13 nov. 1902 .

52. La Nación, Buenos Aires, p. 2,23 dic. 1902 .

53. La Nación, Buenos Aires, p. 6,11 dic. 1902 . 
54. Cf. Parque Colón... (1985, p. 11, 47). Se proyectó según la ordenanza $\mathrm{n}^{\circ}$ 27549 del 28 de septiembre de 1894 , como parte de las obras del puerto llevadas a cabo por Eduardo Madero. Carlos Thays fue su autor, paisajista francés llegado a la RepúblicaArgentina en 1889 desde París y quien trabajó en la Dirección de Paseos de la Capital desde 1891 hasta su muerte en 1934.

55. EL PASEO DE JULIO. $\mathrm{La}$ Nación, Buenos Aires, año 1 , n. 41,11 jun. 1903 . Suplemento Ilustrado, [s. p.]
La inauguración

Esta fuente se convertiría en la primera realizada en mármol de Carrara para ser emplazada en la ciudad, obra de una artista formada en Europa becada por Estado. Era una obra decorativa destinada a que el paseante pudiese contemplar y disfrutar.

Finalmente el Paseo de Julio fue el sitio elegido, una zona de la ciudad donde años antes había estado la estación del ferrocarril Central Argentino y que por esta época Carlos Thays, como Director de Paseos, estaba proyectando el parque que se inauguraría en $1904^{54}$ (Figura 5).

El Paseo de Julio era considerado el sitio más popular de la ciudad. En la zona de "el Bajo", como se la conocía, el transeúnte

busca alli sus distracciones, porque goza con la gritería multiforme y múltiple de los organillos chillones, de los pregoneros de remates, de las campanillas de los espectáculos, de las imprecaciones lunfardas [...] El Bajo es atrayente, porque allí se puede ir [...] á palpar ese cosmopolitismo de que está saturada la capital. La inmigración se vuelca en sus contornos y se muestra al desnudo con todos sus caracteres ${ }^{55}$.

La fuente es incorporada a ese espacio cosmopolita, lugar de tránsito constante en el que algunos de los inmigrantes que habían llegado a la ciudad desde tierras lejanas venden mercancías, hay casas de remates, música de los organitos, con un idioma que surge de la mezcla de nacionalidades, y modifica visualmente el espacio con su iconografía, los desnudos, los chorros de agua, la pureza del mármol.

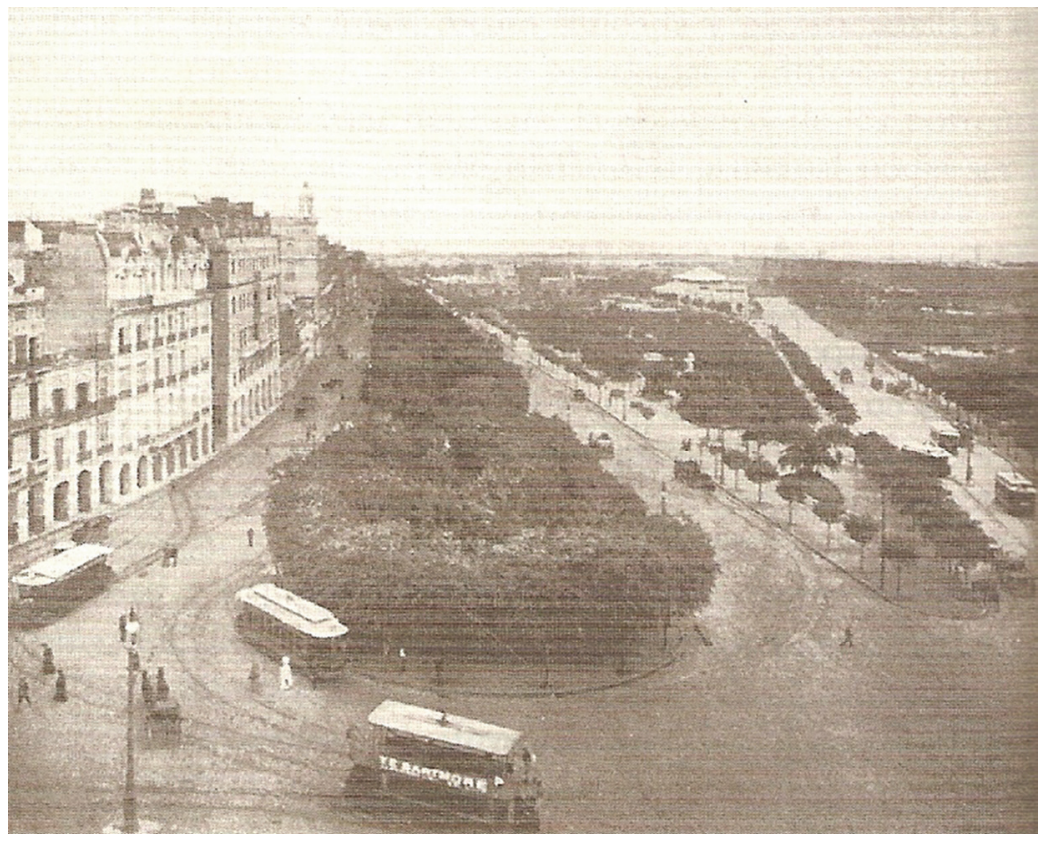

182
Figura 5 - El Paseo de Julio, hoy Avenida Leandro N. Alem, visto desde la Casa de Gobierno (c. 1910). A la derecha de la fotografía, entre el follaje de los árboles del cantero de forma triangular, asoma la figura de Venus de la fuente. Archivo Fotográfico del Archivo General de la Nación (BRAUN; CACCIATORE, 1996, p. 62). 
El Paseo de Julio, lugar de la ciudad que se quiere reformar, embellecer y transformar, incorpora la tradición escultórica de las fuentes italianas que se refleja en la concepción iconográfica-tipológica (Figura 6).

Para Lola Mora, era importante la orientación de cada una de sus esculturas de acuerdo a su significado y simbología. La figura de Venus que corona el conjunto escultórico, estaba dirigida hacia la Casa de Gobierno y el Parque Colón, proyectado unos años antes. Lola Mora dirigió los trabajos de instalación (como así también lo hizo durante el traslado de su fuente en 1918 a la zona sur de la ciudad).

La inauguración se produce el día 21 de mayo de 190356. Se anunciaba un acto sencillo aunque con la prometida presencia del presidente de la República, el intendente municipal y otros funcionarios ${ }^{57}$ (Figura 7).

El diario La Nación da testimonio del acto destacando, por un lado, las actitudes de la artista en las instancias previas, las últimas instrucciones, su orgullo y alegría por la tarea cumplida y, por otra parte, la presencia del público, aspecto que se privilegia ante la poca importancia de la presentación oficial de la fuente "en sociedad".

El acto contó con la presencia de algunos funcionarios como el ministro del Interior, doctor Joaquín V. González quien va en representación del Presidente Roca, el Dr. Carlos Pellegrini, el Ministro en Italia Enrique B. Moreno, Ernesto Tornquist, los comisionados municipales Manuel Mujica Farías, Ernesto de la Cárcova, Mariano Martínez, Martín Biedma, el Director de Paseos Carlos Thays ( 1849-1934) y el intendente municipal en ejercicio Alberto Casares:

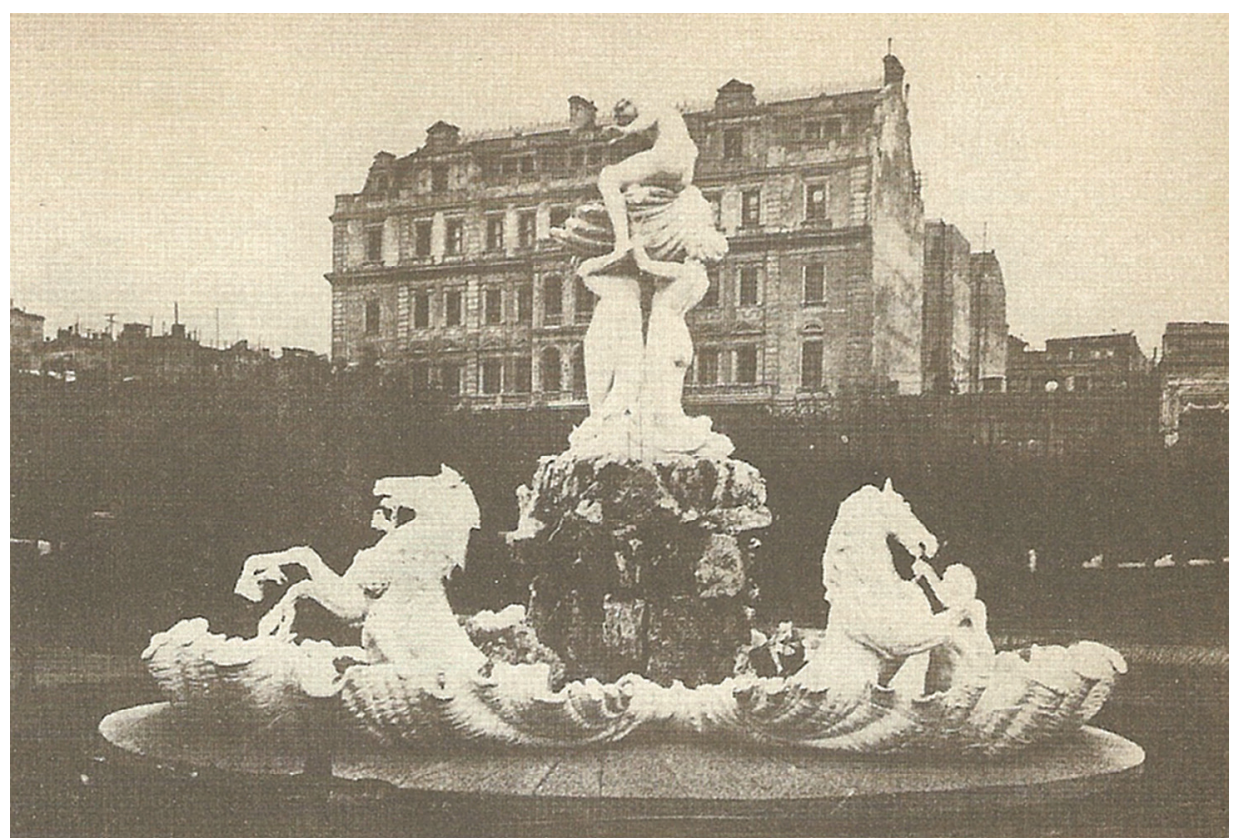

Figura 6 - Fuente de Lola Mora en su emplazamiento original (foto sin fecha). Caja 3234, foto 319.780, Archivo Fotográfico del Archivo General de la Nación, Buenos Aires. 


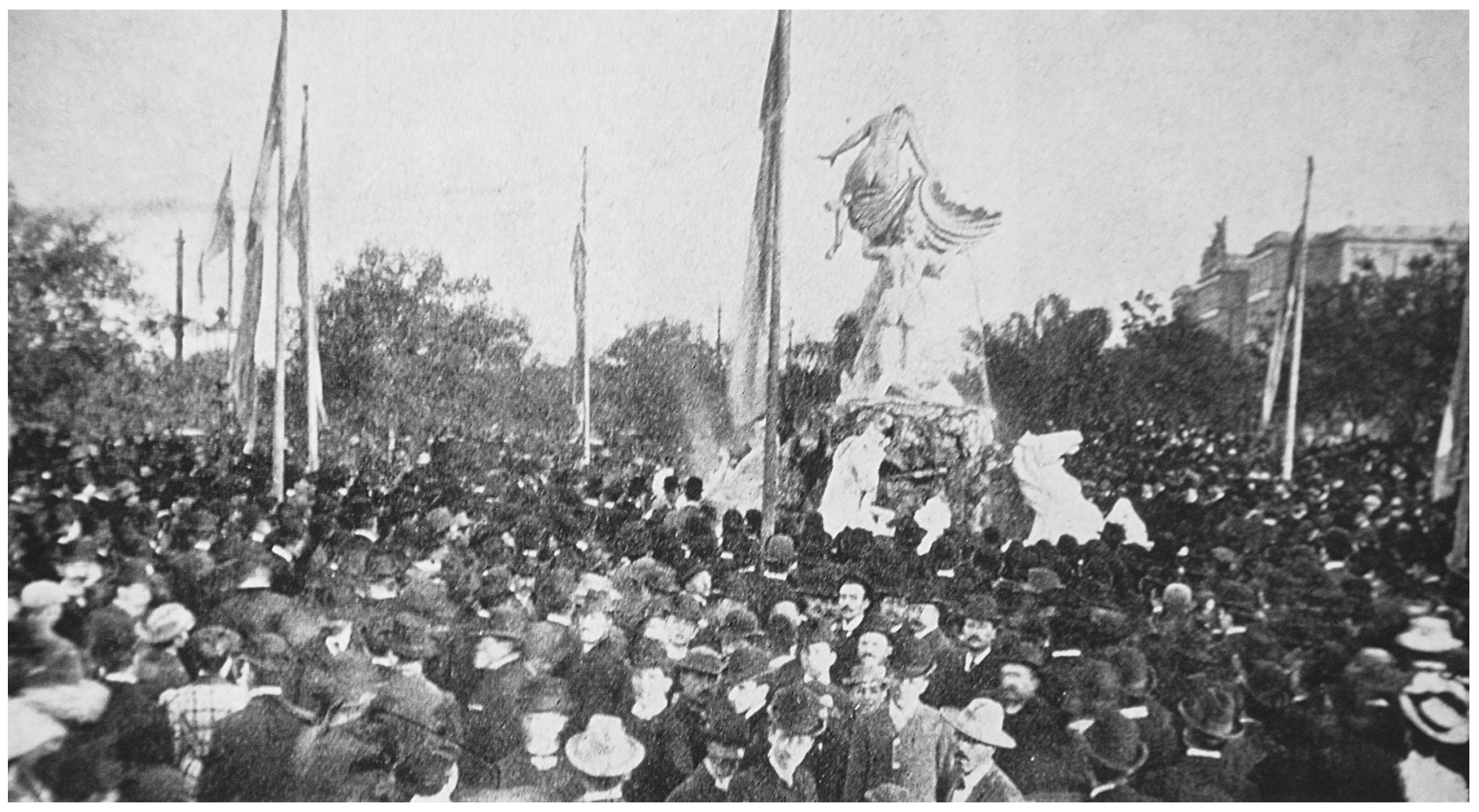

Figura 7 - Inauguración de la fuente en el Paseo de Julio. La Nación, 28 mayo 1903. Suplemento llustrado.

58. La Nación, Buenos Aires, p. 6-7, 22 mayo 1903.

59. Véase Inauguración de la fuente de Lola Mora. Caras $y$ Caretas (1903).
La fuente estaba oculta al público por medio de una cenefa, y á su alrededor se habían colocado algunas banderas argentinas [...] La Srta. Mora, con su nerviosidad acostumbrada, recorría de un extremo á otro el reducido espacio que ocupa la fuente, dando las últimas instrucciones á los operarios para cuando llegara el caso de abrir las llaves para dar salida á las diversas corrientes de agua, interrumpiendo á cada instante esta preocupación para retribuir ya un saludo, ya una felicitación de los presentes.

En un momento la vimos sentada en uno de los bordes de la fuente, contemplando su obra, triunfante y justamente orgullosa de su talento, ya consagrado de antemano y confirmado ayer por el pueblo que la aclamó vencedora, vitoreandola con entusiasmo.

Si su corazón de artista no se ha sentido satisfecha ante la indiferencia de las autoridades, por la pobreza del acto de ayer, en cambio, ha tenido una compensación en las manifestaciones que el pueblo soberano le prodigó ${ }^{58}$.

Sin embargo los diarios, además de criticar la pobreza del acto realizado, hacen lo propio con el lugar en que la obra fue emplazada, en un paseo que aun no había sido terminado, aunque la fuente se destacaba sobre un fondo de árboles de los jardines que la rodean ${ }^{59}$ :

El público [que formó un círculo] no dejó de visitarla hasta las últimas horas del día. Las apreciaciones que se oían eran unánimente [sic] elogiosas, lamentándose que la fuente no se hubiese colocado en lugar más visible, donde se pudiese destacar mejor en su concepción monumental y en sus armónicas proporciones. Las tres figuras de mujer, sobre todo, son de una delicadeza y finura de líneas excepcionales y revelan las dotes de la artista y el primor 
con que ha cuidado hasta los menores detalles. Esas estatuas podrían figurar con honor en cualquiera de los mejores monumentos de Europa ${ }^{60}$ (Figura 8).

El periódico La Protesta destaca la calidad de la fuente analizando la obra meses después, en especial halaga la resolución de la anatomía de los cuerpos representados, el estudio del cuerpo y la serenidad de cada gesto:

Lola Mora con su fuente del Paseo de Julio, ha logrado despertar en el espíritu de la multitud esa muda admiración que la belleza produce.

El desnudo está estudiado profundamente. La artista ha logrado sorprender en su obra de arte, toda la belleza física de los seres humanos.

El lineamiento general de aquellos cuerpos de mujeres es exacto. Nada es violento en su actitud. Un profundo conocimiento anatómico se releva en aquellas espaldas, brazos y piernas marmóreas. La musculatura, los biceps de los atletas impresionan vivamente, lo mismo que la actitud briosa de los corceles. Todo, en aquella hermosa obra de un talento poderoso, revela á la mujer de genio que sigue una ruta nueva para el ambiente anémico de la sociedad presente ${ }^{61}$ (Figura 9).

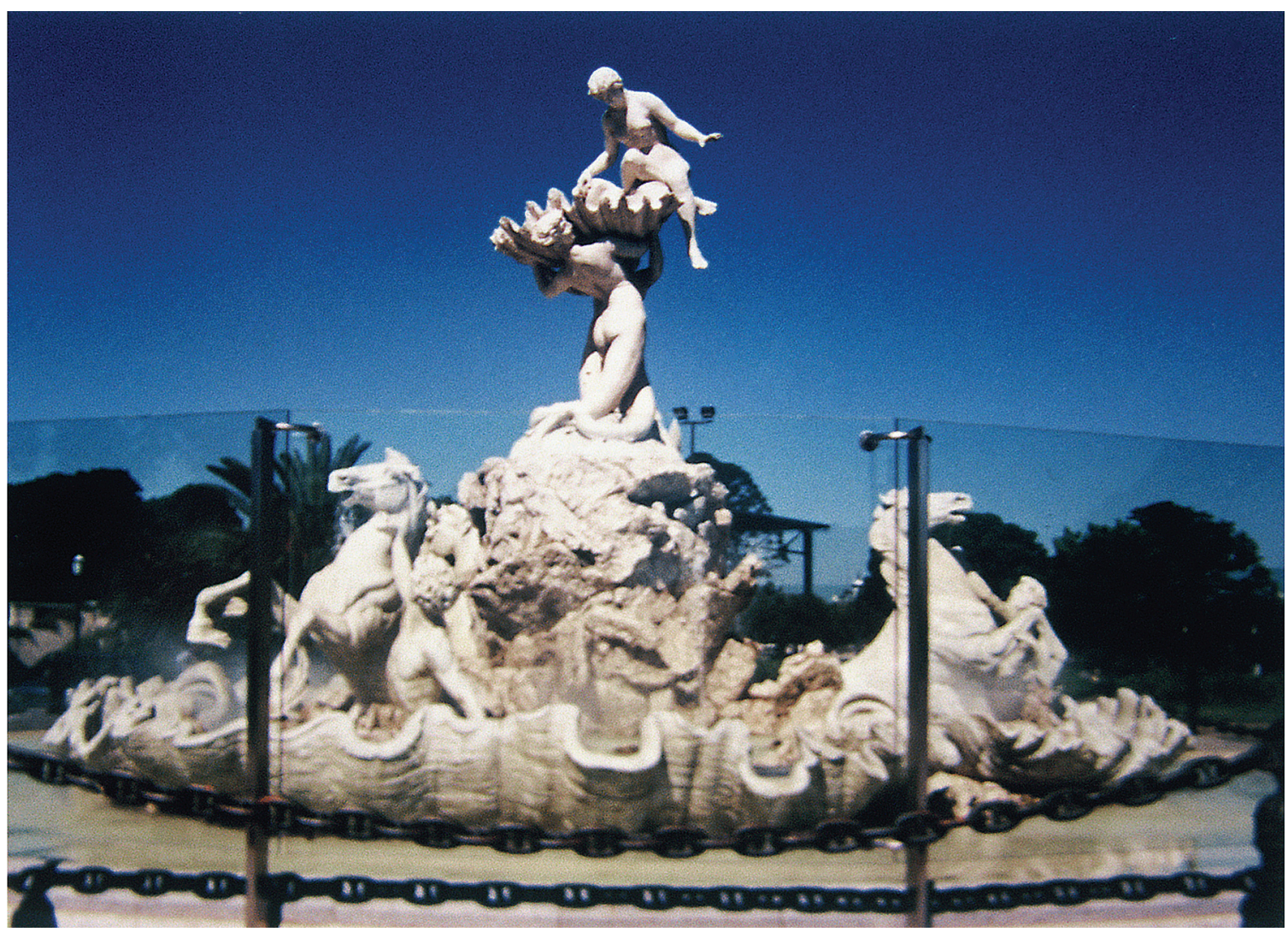

Figura 8 - Fuente de Lola Mora (actual emplazamiento, Costanera Sur), enero de 2001, foto Patricia Corsani. 


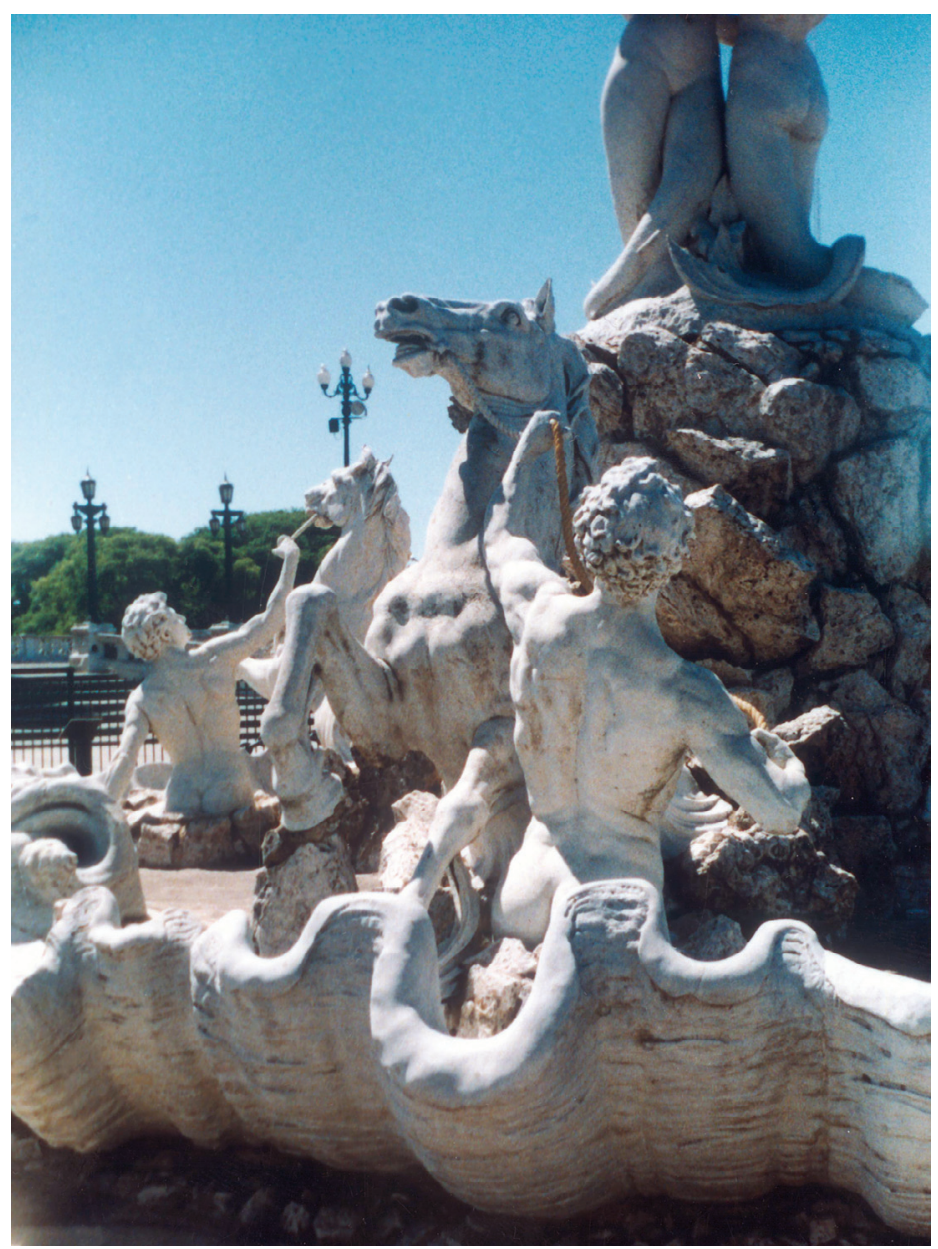

Figura 9-Fuente de Lola Mora. Detalle lactual emplazamiento, Costanera Surl, diciembre de 1999, foto Patricia Corsani.

Sin embargo, no podemos dejar de hacer referencia a lo complejo de la tarea para profundizar en la recepción que tuvo el conjunto escultórico por los escasos testimonios escritos que relaten otros aspectos en juego. Solo algunos datos aislados en noticias posteriores e incluso de publicaciones extranjeras, dejan filtrar algunos malestares y descontentos de ciertos grupos que habitaban la ciudad.

El público recibió con entusiasmo la fuente que no le fue indiferente y produjo una alta dosis de curiosidad. Podríamos suponer que este interés tiene relación con diversas cuestiones: participar en la inauguración de la primera fuente realizada en mármol; la atracción que les producía esta obra cuya autora era una mujer, hecho nuevo para la ciudad; saber cómo era esta fuente que había sido objeto de debates en torno a ésta, y, los desnudos que presentaba.

El hecho es que durante todo el día la gente la visitó cual una procesión, fue elogiada y admirada por hombres, mujeres y niños que la rodearon. 
La prensa escrita porteña nunca dejó de informar al lector al tiempo que lo hacía reflexionar y lo acercaba al centro del conflicto. Siguió paso a paso todo el proceso desde la aceptación de la primera maqueta de la escultora hasta la inauguración y los debates posteriores. Las estrategias de la escultora para lograr el triunfo fueron difundir su trabajo y conectarse con el lector a través de la prensa y, a lo que se suman sus vinculaciones políticas.

Y después del emplazamiento... Una carta de Lola Mora al Intendente Municipal

Sin embargo, al entusiasmo popular por tener la fuente en un paseo público de la ciudad y el orgullo que su autora haya sido una argentina, le siguen los comentarios sobre la situación financiera de Lola Mora, que no tuvo un rédito económico por este trabajo. Los medios gráficos apoyan a la escultora y aconsejan a la municipalidad le otorgue alguna gratificación por su obra ${ }^{62}$.

Pero, siempre hemos de ser lo mismo... Todo está lindo, todos gozan y admiran la obra, y el bolsillo de la artista está vacío. Aún se está discutiendo la remuneración que ha de tener por su feliz creación artística.

Vamos; estas cosas no se discuten, ni tienen que meditarse, sobre todo, cuando ya se han pronunciado sobre la materia la inteligencia y el arte $^{63}$.

El fracaso económico de la artista, se destaca también en la sección "De la semana" de Caras y Caretas del 6 de junio de 1903 que - con el título Arte libre - publica un dibujo con Lola Mora y un señor ante la fuente quien le pregunta a la escultora: " - Es muy linda; pero ż por qué ha puesto usted las mujeres desnudas?" y Lola Mora responde:

- Porque no me alcanzó la plata para vestirlas ${ }^{64}$.

Por un lado, esta escena remite al conflicto económico surgido en torno a este encargo y la situación financiera de la artista que apenas pudo cubrir los gastos de la obra. El debate, llegó a una instancia en que la obra misma o lo que transmitía quedó en un segundo plano.

En las notas de la inauguración se pone en evidencia cierta desconfianza respecto a la posibilidad que la escultora no entregase la obra terminada a tiempo. Y, dadas las altas recomendaciones que tenía, éstas se consideraban elementos fundamentales que habrían justificado esa "impunidad" de la artista:

Y así entre estos juicios el público esperó la fuente con tranquila indiferencia, sospechando ingenuamente uno de los tantos derroches de favoritismo oficial ó quizá una de las frecuentes incursiones que el patrioterismo suele hacer en el terreno del arte.

Pero se ha levantado la fuente y esto ha bastado para que todo el mundo se dé cuenta de la injusticia en que se había complicado contra esta compatriota llena de originalidad y de
62. La Nación, Buenos Aires, p. 6-7, 22 mayo 1903.

63. La Voz de la Iglesia, Buenos Aires, p. 1, 5 jun. 1903.

64. Caras y Caretas (1903b). 
65. La Nación, Buenos Aires, p. 5,2 jun. 1903.

66. Véase Carlos Páez de la Torre y Celia Terán (1997, p. 14-16).

67. Idem.p. 34, 38

68. Cf. Elaine Dias (2006).

69. Cf.Anne Higonnet (2000, p. 329).

70. En Carlos Páez de la Torre y Celia Terán (1997, p. 45). buen gusto. [...] Hoy no existe más que una opinión, y es la que sofocando envidias estrechas y pérfidas reticencias consagra las eminentes condiciones de esta singular artista, admirablemente dotada para la concepción y para la factura, y tan digna del estimulo de sus compatriotas ${ }^{65}$.

A pesar de realizar también esculturas para particulares tanto en su taller romano como en la ciudad de Buenos Aires, no obstante esto, recibe encargos oficiales que, en su mayor parte, se efectivizaron durante la segunda presidencia de Julio A. Roca. Su padre había sido un comerciante y hacendado en Tucumán y ella era parte de una familia numerosa de cuatro hermanas (ella había sido la tercera mujer) y tres hermanos ${ }^{60}$. Pariente muy lejana de Juan B. Alberdi, estadista y escritor, Lola estudia en la ciudad de San Miguel de Tucumán pero todos pasan temporadas también en Trancas. La beca obtenida para concretar sus estudios europeos se la debe a intervenciones del gobernador tucumano Araoz, al Ministro Soldati, al diputado nacional Próspero Mena y, a Dardo Rocha, fundador de la ciudad de La Plata que redacta una nota de presentación al embajador en Roma Dr. E. Moreno ${ }^{67}$. Estas personalidades son las que apoyaron a la escultora en sus inicios, probablemente todos vinculados directa o indirectamente en algún momento de su vida a su padre Romualdo Alejandro Mora (1835-1885).

Sin embargo, hay menciones en la prensa extranjera que hacen referencia a cuestionamientos surgidos en Buenos Aires y relacionados, por ejemplo con las figuras de las sirenas; o consideraciones generales sobre la recepción de su arte. Si existió algún cuestionamiento a su iconografía, a los desnudos de sus figuras o a su autora de parte de algún sector de la sociedad la prensa argentina de esos años no lo refleja de manera directa en sus páginas.

El hecho que se haya dejado de lado el primer sitio propuesto para emplazar la obra que era la Plaza de Mayo (frente a la iglesia Catedral), centro cívico, religioso y político de la ciudad, es particularmente sintomático. Para la ciudad de Buenos Aires de esos años exponer desnudos públicamente era atentar contra la moral preestablecida. El desnudo es un género que, si bien define la calidad del artista que lo trabaja, es un tema que inquieta, que afecta en algunos casos a la moral y el "buen gusto" 68 . Recordemos que el estudio del desnudo se llevaba a cabo a partir del modelo vivo y era fundamental en la formación académica.

A esto se agrega que la autora de esos desnudos era una mujer que, además se dedicaba profesionalmente a la escultura, un oficio propio de hombres. Anne Higonnet escribe que "Las formas de trabajo menos femeninas resultaban extremadamente difíciles de asimilar para la cultura visual" 69 . Por eso el hecho de que una mujer eligiese la escultura como su forma de vida, actividad que requería sobretodo de la fuerza física, producía una ruptura con el modelo culturalmente aceptado de pintora aficionada o artesana.

Lola Mora trabajaba en su taller usando un atuendo particular que consistía en unas bombachas salteñas bastante holgadas, una túnica larga de color gris, una boina vasca de las que se usaba en la localidad tucumana de $\operatorname{Trancas}^{70}$. En definitiva era un traje de características masculinas, que, a pesar de ser habitual 
en otras artistas extranjeras de la época (por ejemplo George Sand, Sara Bernhardt) ${ }^{71}$ no dejaba de llamar la atención de la prensa de Buenos Aires. El hecho que una mujer llevara pantalones, establecía que era capaz de invadir un lugar que había sido exclusiva propiedad del hombre y que podía hacer las mismas cosas, era una transgresión a lo socialmente permitido (Figura 10).

Asimismo, Lola Mora invade áreas públicas e irrumpe en espacios de sociabilidad propiamente masculinos participando de sus rituales sociales, como su presencia y agazajos en el exclusivo Club del Progreso, la participación en recepciones en honor a delegaciones extranjeras o en los almuerzos con distintas figuras del poder político, además de sus entrevistas con intendentes u otros funcionarios ${ }^{72}$.

La escultora era una mujer audaz y que mantenía, durante estos primeros años del siglo, un diálogo constante y directo con los actores del campo del poder que le permitía permanecer en una posición codiciada pero en la que recibía críticas de algunos artistas del momento como Eduardo Schiaffino, por entonces Director y fundador del Museo Nacional de Bellas Artes. Es interesante leer fuentes hemerográficas de este período que estuvimos analizando y de los años posteriores a la presidencia de Julio A. Roca (que culmina en 1904), pues a partir de ese momento se observan con más claridad los enfrentamientos, las opiniones contra su trabajo y las críticas a su manera de proceder ante proyectos que parecía tener ganados de antemano. Con Roca en Europa y alejado del

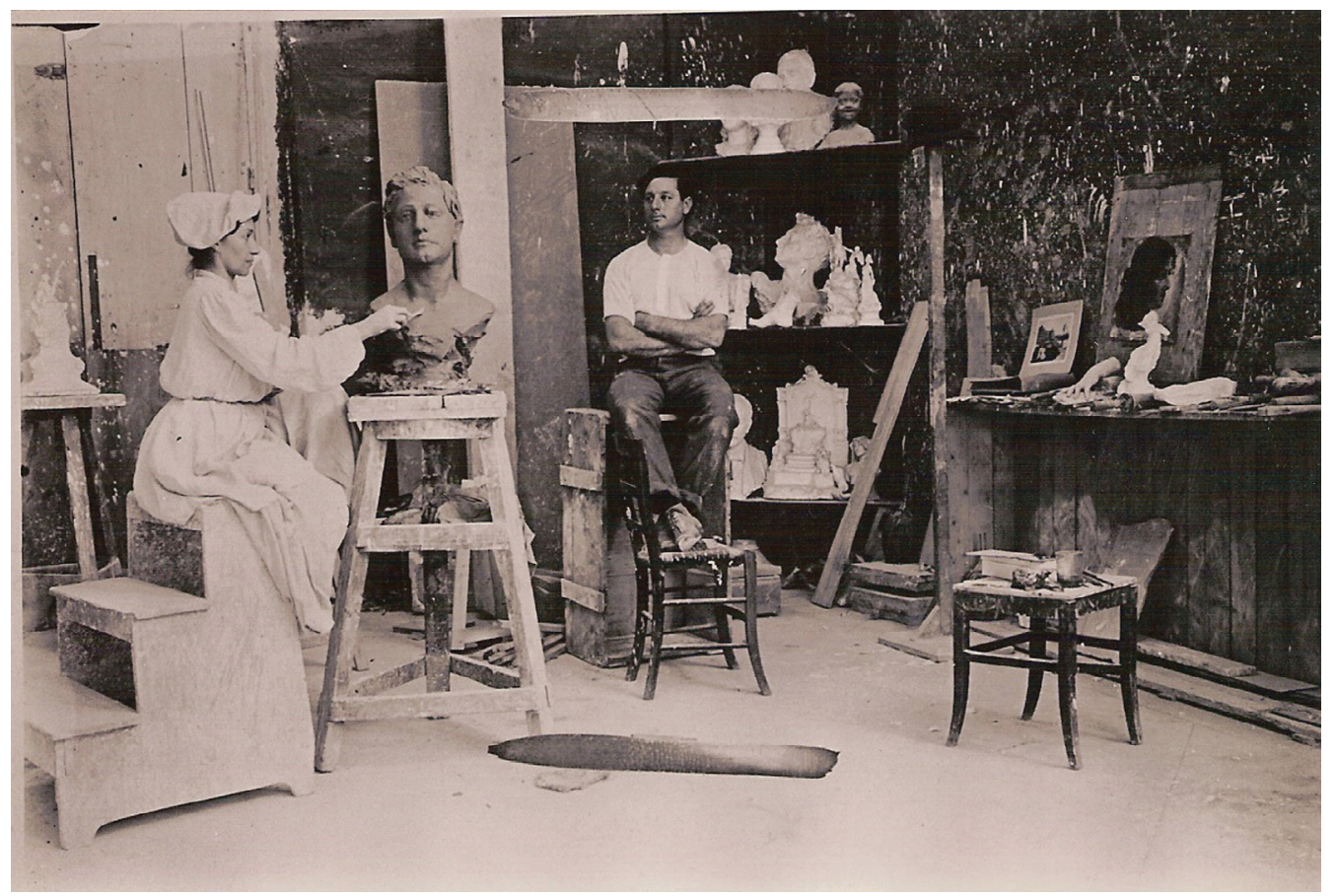

Figura 10 - Lola Mora trabajando en su taller en Roma. 1905. Caja 1210, foto 108.051, Archivo Fotográfico del Archivo General de la Nación, Buenos Aires.
71. Cf. Las mujeres en traje masculino, Caras y Caretas (1907).

72. Para el primer banquete véase: El Pais, Buenos Aires, p. 5, 5 jun. 1903; idem, p. 5, 6 jun. 1903; El banquete á Lola Mora. Caras y Caretas (1903). Para el segundo: Los banquetes al Dr. Quirno Costa y Lola Mora. Caras y Caretas (1903). 
73. Véase Justo Solsona (1903).

74. Cf. Bram Dijkstra (1986, p. $250,267-268)$.

75. La Nación, Buenos Aires p. 7,23 nov. 1903 .

76. La Protesta, Buenos Aires, año 8,n.316,p.2,9 jun. 1904. gobierno su futuro laboral se hace más difícil: proyectos inconclusos o rechazadas, destrucción del monumento a Aristóbulo del Valle víctima de un atentado por desconocidos, hechos que entorpecen la concreción de varias de sus propuestas, temáticas que exceden los límites de este trabajo.

En fin, en una entrevista publicada en una revista de Barcelona realizada por Justo Solsona a Lola Mora, se dejan en evidencia algunas de las críticas a sus esculturas:

Se ha censurado que las sirenas se salgan de la leyenda, siendo perfectas mujeres hasta medio muslo, de donde empiezan las escamas, terminando las piernas en dos curvas colas como las de los peces 'sirenios'; y no hasta la cintura solamente, como nos las pintan los dibujos antiguos. Injusta censura y más injusta todavía cuando cinturas, caderas, vientres y muslos están tratados magistralmente. En creaciones fantásticas, la más bella y artística es la más acertada. [...] j En su tierra natal, pues, lejos de las facilidades de los grandes centros de cultura, desarrolló sus aptitudes la celebrada artista argentina, sin otro acicate que la local chismografía, dura y despreciativa, cuanto envidiosa é ignorante ${ }^{73}$.

En el siglo XIX se consideraba que la representación de los desnudos de ninfas, sirenas, mujeres-pez, provocaban y confundían la mente de los hombres originando la tensión entre miedos, fantasías y deseos con sus actitudes agresivas e irracionales, esto se agrega a la decisión de la escultora de tratar un tema mitológico y de los desnudos de la diosa Venus y el resto de las figuras que la acompañan ${ }^{74}$.

La síntesis de estas tensiones la leemos en el diario La Nación donde, meses después de la inauguración de la obra, transcribe un artículo que se publicó en La Patria de Roma en el que alude directamente a estos conflictos que afectaron el trabajo de la artista: "El camino que ha hecho Lola Mora ha sido, si no largo, áspero; [...] no se ha anunciado un concurso de escultura sin que ella haya tomado parte en él, y pocos han sido los que no han importado un triunfo para ella, no obstante la hostilidad de sus cofrades masculinos y de sus hermanos argentinos... nemo propheta..."75.

En otros periódicos de Buenos Aires como La Protesta, en un tono más combativo se dirige abiertamente a todos aquellos que se opusieron a la propuesta de la escultora. Estos comentarios confirman el malestar causado por la presencia de una obra de estas características en la ciudad. Y varios meses después de la inauguración de la obra leemos:

Después de la gritería arrancada á los mojigatos y pudibundos fementidos de la clase privilegiada, su obra ha merecido la justa sanción de los despojados de todo prejuicio.

La obra artística de Lola Mora vive porque es obra de verdad y seguirá viviendo mal que le pese á los degradados moralistas de la burguesía, que ven un atentado á la moral pública en la exibición [sic] descarada de un desnudo, y no ven como inmoral ciertas inversiones de la naturaleza humana ${ }^{76}$

El 24 de junio de 1903 el diario La Nación y El País publican, días después de la inauguración de la fuente en el Paseo de Julio, una valiosa carta que Lola Mora enviara al Intendente Municipal. En esta misiva, la escultora 
sintetiza las dificultades y gastos que tuvo que enfrentar durante su permanencia en Buenos Aires, consecuencia de las demoras del emplazamiento del conjunto escultórico. Al mismo tiempo agradece y hace una renuncia formal a favor de la municipalidad del dinero que la comisión municipal le había asignado días antes por su trabajo.

Transcribimos el documento en su totalidad por considerarlo uno de los pocos testimonios directos que conocemos de la escultora:

El señor intendente se ha servido hacerme saber que ha promulgado la ordenanza de la $\mathrm{H}$ [Honorable] comisión municipal, que me acuerda diez mil pesos como compensación del trabajo artístico que me encomendó la municipalidad de la capital.

Acepto con el mayor agradecimiento la idea, honrosa para mi [sic], de acordarme una compensación por la obra de arte y ruego al señor intendente se digne comunicarlo á la H. comisión, expresándole al mismo tiempo, que me es satisfactorio corresponder á esa resolución, renunciando, en favor del erario municipal á lo que me adeuda por los siguientes conceptos.

Por el contrato que la intendencia celebró conmigo quedé obligada á entregar la fuente á S. E. el señor ministro argentino en Italia, por la cantidad de veinticinco mil pesos de curso legal. Cumplido ese compromiso, me trasladé á esta ciudad á pedido del intendente anterior, señor Bullrich, para dirigir personalmente la construcción de la fuente y traje dos operarios costeados por mí, que ya he hecho regresar á Italia.

El trabajo ha demorado mucho más de lo necesario, por la lentitud de los procedimientos administrativos, como el señor intendente lo ha declarado en un decreto comunicado á la $\mathrm{H}$. comisión; de modo que él importa para mí un viaje de cerca de un año, con abandono de mi taller, que es mi único recurso de vida y con todos los gastos consiguientes de traslación y permanencia en esta capital, habiendo recibido para esto los mil doscientos pesos moneda nacional, votados en diciembre por la H. comisión, expresando que se me entregasen por mi trabajo y el de mis ayudantes.

Séame permitido, por esto, manifestar, la persuasión de que no he sido gravosa al erario municipal con el costo de la obra de arte, ni tampoco con los gastos y perjuicios que me ha requerido su erección en el Paseo de Julio.

Me es satisfactorio expresar al señor intendente mi agradecimiento por las atenciones que me ha dispensado durante el trabajo y tengo el honor de saludarlo con toda consideración. - Lola Mora ${ }^{77}$.

Evidentemente y para concluir, esta renuncia demuestra que Lola Mora se sentia al margen de cualquier conflicto surgido alrededor de su obra, su lugar era el del arte. La inversión de tiempo, trabajo y dinero en Buenos Aires afectó seriamente sus finanzas pero su nobleza estaba por encima de lo que había ocurrido. Hace en esta carta, un manifiesto, una firme defensa de su profesión de escultora, del trabajo y del esfuerzo de ella y sus ayudantes, agradece y, a la vez, pide disculpas dando por cerrada, desde su lugar, esta eterna querella.
77. El Pais, Buenos Aires, p. 5, 24 jun. 1903. También en: La Nación, Buenos Aires, p. 8, 24 jun. 1903. La carta está fechada: Buenos Aires, 23 jun. 1903. 


\section{REFERENCIAS}

\section{A - Libros y artículos en periódicos, con autoria declarada}

AGUERRE, Marina; PICCIONI, Raúl. Eduardo Schiaffino y "el monito titi” del Parque 3 de Febrero, o la introducción de una estética moderna en la empresa monumental porteña. In:WECHSLER, Diana Beatriz (Coordinadora). Desde la otra vereda: momentos en el debate por un arte moderno en la Argentina (1880-1960). Buenos Aires: Jilguero, 1998. p. 83-117 (Archivos del Caia, 1).

AGULHON, Maurice. Historia vagabunda. México: Instituto Mora, 1994.

BERJMAN, Sonia. Plazas y parques de Buenos Aires: la obra de los paisajistas franceses. 18601930. Buenos Aires: Fondo de Cultura Económica, 1998.

BRAUN, Clara; CACCIATORE, Julio. El imaginario interior: el intendente Alvear y sus herederos. Metamorfosis y modernidad urbana. In:VÁZQUEZ-RIAL, Horacio (Dir.). Buenos Aires 1880-1930: la capital de un imperio imaginario. Madrid:Alianza, 1996. p. 31-71.

BUCICH ESCOBAR, Ismael. Buenos Aires Ciudad: en el cincuentenario de su federalización. 18801930. Buenos Aires: El Ateneo, 1930.

CORSANI, Patricia V. La fuente de Lola Mora en el Paseo de Julio. Una nueva lectura de su instalación a través de la prensa escrita (1900-1903). In:TERCERAS JORNADAS ESTUDIOS E INVESTIGACIONES EUROPA/LATINOAMERICA.ARTES PLASTICASY MÙSICA.BuenosAires,Instituto de Teoría e Historia del Arte Julio E. Payró-Facultad de Filosofía y Letras (UBA), 1999. Edición en CD Rom.

. Hermosear la ciudad: Ernesto de la Cárcova y el plan de adquisición de obras de arte para los espacios públicos de Buenos Aires. In: JORNADAS ESTUDIOS E INVESTIGACIONES: Imágenes-Palabras-Sonidos. Practicas y Reflexiones, 4. Buenos Aires, 2000. Actas... Buenos Aires: Instituto de Teoría e Historia del Arte Julio E. Payró-Facultad de Filosofía y Letras, Universidad de Buenos Aires, 2000. p. 249-262.

La fuente de Lola Mora en el 'Balneario Fantástico'. Avances. Revista del Área Artes: 20012002, Córdoba, Centro de Investigaciones de la Facultad de Filosofía y Humanidades-Universidad Nacional de Córdoba, n. 5, p. 47-59, oct. 2002.

DIAS, Elaine. El estudio del desnudo en el siglo XIX: la academia francesa y sus modelos. In: BONDONE,Tomás (Cur.). El Desnudo en la Academia. Córdoba,Arg.: Escuela Superior de Bellas Artes Dr. José Figueroa Alcorta; Ciudad de las Artes, 2006. p. 11-23.

DIJKSTRA, Bram.Ídolos de perversidad: la imagen de la mujer en la cultura de fin de siglo. Madrid: Debate, 1986.

ENCICLOPEDIA Italiana di Scienze, Lettere ed Arti, 12. Roma: Istituto Giovanni Treccani, 1934. $23 \mathrm{v}$.

FOURNIER, Paul. Lola Mora y su obra. La Protesta, Buenos Aires, año 8, n. 316, p. 2, 9 jun. 1904.

GESUALDO, Vicente. Enciclopedia del Arte en América. Biografías I. Buenos Aires: Omeba, 1969.

GIANELLO, Leoncio; PICCIRILLI, Ricardo; ROMAY, Francisco L. Diccionario bistórico argentino, t. I. Buenos Aires: Ediciones Históricas Argentinas, 1954. 
GORELIK,Adrian. La grilla y el parque: espacio público y cultura urbana en Buenos Aires 18871936. Buenos Aires: Universidad Nacional de Quilmes, 1998.

GUTIÉRREZ VIÑUALES, Rodrigo. Monumento conmemorativo y espacio público en Iberoamérica. Madrid: Cátedra, 2004.

HAEDO, Oscar Félix. Lola Mora: vida y obra de la primera escultora argentina. Buenos Aires: Eudeba, 1974.

. Las fuentes porteñas. Buenos Aires: Municipalidad de la Ciudad de Buenos Aires, 1978 (Cuadernos de Buenos Aires, 51).

HIGONNET,Anne. Mujeres e Imágenes: representaciones. In: Fraisse, Geneviève; Perrot, Michelle. Historia de las mujeres en Occidente 4: El siglo XIX. Madrid:Taurus, 1993. p. 369-398.

MERLINO,Adrián. Diccionario de artistas plásticos de la Argentina. Siglos XVIII-XIX-XX. Buenos Aires:Adrián Merlino, 1954.

PÁEZ DE LA TORRE, Carlos [hijo];TERÁN, Celia. Lola Mora: una biografía. Buenos Aires: Planeta, 1997.

PARQUE COLÓN. La aduana nueva. Buenos Aires: CPC, 1985 (Buenos Aires nos cuenta, 9).

PICCIONI, RAÚL. La estética de la ciudad. Preocupaciones de un pintor. In:JORNADAS ESTUDIOS E INVESTIGACIONES: Imágenes-Palabras-Sonidos. Practicas y Reflexiones, 4. Buenos Aires, 2000. Actas... Buenos Aires: Instituto de Teoría e Historia del Arte Julio E. Payró-Facultad de Filosofía y Letras, Universidad de Buenos Aires, 2000. p. 17-26.

SOLSONA, Justo. Lola Mora. La Ilustración Artística, Barcelona, año 22, n. 1138, 19 oct. 1903, p. 686-687 (editado por: Montaner y Simón. Fecha del artículo: Buenos Aires, agosto de 1903).

SOSA DE NEWTON, Lily. Diccionario biográfico de mujeres argentinas. Buenos Aires: Plus Ultra, 1986.

VAN DEURS, Adriana; RENARD, Marcelo. El monumento "antiguo" de Colón. Estudios e Investigaciones: Instituto de Teoría e Historia del Arte Julio E. Payró de la Facultad de Filosofía y Letras, Universidad de Buenos Aires, Buenos Aires, n. 6, p. 127-131, 1996.

\section{B - Documentación en periódicos, sin autoria declarada:}

a)Caras y Caretas:

ARTE Y ARTISTAS. La fuente de Lola Mora. Caras y Caretas, Buenos Aires, año 6, n. 225, [s. p.], 24 enero 1903.

EL BANQUETE á Lola Mora. Caras y Caretas, Buenos Aires, año 6, n. 245, [s. p.], 13 jun.1903.

INAUGURACIÓN de la fuente de Lola Mora. Caras y Caretas, Buenos Aires, año 6, n. 243, [s. p.], 30 mayo 1903.

LAS MUJERES en traje masculino. Caras y Caretas, Buenos Aires, año 10, n. 440, [s. p.], 9 marzo 1907. 
LOS BANQUETES al Dr. Quirno Costa y Lola Mora. Caras y Caretas, Buenos Aires, año 6, n. 248, [s. p.], 4 jul. 1903.

UNA ARTISTA argentina. Caras y Caretas, Buenos Aires, año 3, n. 98, [s. p.], 18 agosto 1900.

MAYOLY NAVARRETE.Arte Libre. Caras y Caretas, Buenos Aires, año 6, n. 244, [s. p.], 6 jun. 1903 b.

b)El Diario:

UNA ARTISTA argentina-Lola Mora. El Diario, Buenos Aires, p. 1, 7 agosto 1900.

ORNATO de Buenos Aires-La fuente de Lola Mora-Adquirida por la municipalidad. El Diario, Buenos Aires, p. 1, 22 agosto 1900.

EMBELlECIMIENTO URBANO. El Diario, Buenos Aires, p. 2, 22 marzo 1902.

LA FUENTE de Lola Mora. El Diario, Buenos Aires, p. 2, 18 jun. 1902.

LA FUENTE de Lola Mora. El Diario, Buenos Aires, p. 1, 23 sept.1902.

LA FUENTE de Lola Mora. El Diario, Buenos Aires, p. 4,9 mayo 1903.

c) El Pais:

BANQUETE a Lola Mora. El Pais, Buenos Aires, p. 5, 5 jun.1903.

EL BANQUETE á la señorita Lola Mora-En el Club del Progreso. El Pais, Buenos Aires, p. 5, 6 jun.1903.

LA FUENTE de Lola Mora. Nota de la artista al Intendente municipal. El Pais, Buenos Aires, p. 5, 24 jun. 1903.

d) La Ilustración Artística

SOLSONA, Justo. Lola Mora. La Ilustración Artística, Barcelona, año 22, n. 1138, p. 686- 687, 19 oct. 1903.

La Nación:

UNA CARTA de Lola Mora. La Nación, Buenos Aires, p. 8, 24 jun.1903. [Carta con fecha del 23 de junio 1903, dirigida al Intendente Municipal Alberto Casares].

EL PASEO de Julio. La Nación, Buenos Aires, año 1, n. 41, 11 jun. 1903. Suplemento Ilustrado, [s. p.].

MOSCA, Ettore. Confraternidad artística italianoargentina-Lola Mora y Eugenio Maccagnani-Dos notables trabajos para la galeria de Presidentes argentinos.Alto-relieve de la declaración de la independencia-la estatua de Garibaldi para Buenos Aires-Variantes introducidos [sic] en el proyecto original-(Especial para La Nación).La Nación, Buenos Aires, p. 5, 5 mayo 1899. 
LA FUENTE de Lola Mora-Una ficción mitológica.La Nación, Buenos Aires, p. 3, 23 abr. 1901.

UNA FUENTE artística. La Nación, Buenos Aires, p. 3, 22 marzo 1902.

LA FUENTE de Lola Mora-Los ultimos trabajos. La Nación, Buenos Aires, p. 3, 2 sept. 1902.

LA FUENTE de la Plaza Colon-Accidente desagradable. La Nación, Buenos Aires, p. 3, 13 sept.1902.

LA FUENTE de Lola Montes [sic]. La Nación, Buenos Aires, p. 6, 17 nov. 1902.

LA FUENTE de Lola Mora. La Nación, Buenos Aires, p. 3, 13 nov. 1902.

LA FUENTE de Lola Mora. La Nación, Buenos Aires, p. 3, 21 nov. 1902.

EXPOSICIÓN artística.La Nación, Buenos Aires, p. 6, 11 dic. 1902.

LICITACIONES. La Nación, Buenos Aires, p. 2, 23 dic. 1902.

LA FUENTE de Lola Mora.La Nación, Buenos Aires, p. 5, 21 mayo 1903.

LA FUENTE de Lola Mora-Su inauguración-enorme concurrencia-exito completo-Una obra artistica. La Nación, Buenos Aires, p. 6-7, 22 mayo 1903.

LA FUENTE de Lola Mora en la Plaza de Julio. La Nación, Buenos Aires, año 1, n. 39, 28 mayo 1903. Suplemento Ilustrado, [s. p.].

LA FUENTE de Lola Mora - Una obra de justicia. La Nación, Buenos Aires, p. 5, 2 jun. 1903.

LA OBRA de Lola Mora-Un juicio de connaisseur y un aplauso de entusiasta. La Nación, Buenos Aires, p. 7, 23 nov. 1903.

e) La Prensa:

LA PIRÁMIDE de Mayo. La Prensa, Buenos Aires, p. 8, 9 jun. 1901.

LA FUENTE de Lola Mora. La Prensa, Buenos Aires, p. 5, 19 mayo 1903 a.

LA FUENTE de Lola Mora. Ceremonia de la inauguración. Gran concurrencia. La Prensa, Buenos Aires, p. 3, 22 mayo 1903b.

f) La Protesta:

FOURNIER, PAUL. Lola Mora y su obra. La Protesta, Buenos Aires, año 8, n. 316, p. 2, 9 jun. 1904.

g) La Voz de la Iglesia:

COMISIÓN municipal. La Voz de la Iglesia, Buenos Aires, p. 2, 23 mayo 1902.

LA FUENTE de Lola Mora .La Voz de la Iglesia, Buenos Aires, p. 2, 12 jun. 1902.

LA FUENTE de Lola Mora La Voz de la Iglesia, Buenos Aires, p. 1, 5 jun. 1903. 


\section{C - Documentación pública:}

a) de la Municipalidad de la Ciudad de Buenos Aires

CONCEJO DELIBERANTE DE LA CIUDAD DE BUENOS AIRES. Evolución Institucional del Municipio de la Ciudad de Buenos Aires. Buenos Aires: Ediciones del Honorable Concejo Deliberante, 1963.

CONCEJO DELIBERANTE DE LA CIUDAD DE BUENOS AIRES. Ordenanza 49.292 del 15 jun.1995 (C. E. 43.841/95).Archivo de la Dirección de Paseos y División de Monumentos y Obras de Arte (MOA) de la Municipalidad de la Ciudad de Buenos Aires, Carpeta n. 22, circunscripción 13 A. [Declara Sitio de Interés Cultural a la fuente de las Nereidas emplazada en la intersección de la Avenida Tristán Achával Rodríguez, Pedro Luis Migone,Avenida Costanera Sur y Brasil].

HONORABLE COMISIÓN MUNICIPAL. La Comisión Municipal, con 22 miembros elegidos con acuerdo del Senado, comienza su mandato el 21 de diciembre 1901 [Versión taquigráfica de la sesión celebrada el día 21 dic. 1901]. [s. p.].

HONORABLE COMISIÓN MUNICIPAL. [Versión Taquigráfica de la sesión celebrada el día 5 de septiembre 1902]. [s. p.].

RESOLUCIÓN del 18 abr. 1902. In: Registro Municipal de la Ciudad de Buenos Aires 1902. Buenos Aires: Imprenta de M. Biedma e Hijo, 1908, p. 59.

SESIÓN DE PRÓRROGA del día 8 jul.1902. In:Actas de la Comisión Municipal de la Ciudad de Buenos Aires. Correspondientes al año de 1902. Buenos Aires: Tip. del Asilo de Reforma de Menores Varones, 1903, p. 354-355.

SESIÓN ORDINARIA del 6 jun. 1902. In:Actas de la Comisión Municipal de la ciudad de Buenos Aires. Correspondientes al año de 1902. Buenos Aires:Tipografía del Asilo de Reforma de Menores Varones, 1903a, p. 295-296.

SESIÓN ORDINARIA del 5 sept. 1902. In: Actas de la Comisión Municipal de la Ciudad de Buenos Aires. Correspondientes al año de 1902. Buenos Aires, Tip. del Asilo de Reforma de Menores Varones, 1903b, p. 438.

b) de la Nación Argentina:

22 $2^{\text {a }}$ SESIÓN ORDINARIA del 12 de julio de 1895. In: CONGRESO NACIONAL. Diario de Sesiones de la cámara de diputados, año 1895. Sesiones ordinarias, I. Buenos Aires: Compañía Sudamericana de Billetes de Banco, 1895, p. 266.

DECRETO [acordando una subvención á la Srta. Dolores Mora, para hacer estudios de bellas artes en Europa]. In: Registro Nacional de la República Argentina, año 1899 (Segundo cuatrimestre). Buenos Aires:Taller Tipográfico de la Penitenciaría Nacional, 1899.

Artigo apresentado em 5/2006. Aprovado em 8/2007. 